\title{
14- Ders kitabı ve bilimsel metin yazarlarının görüșlerine göre uluslararası öğrencilere akademik Türkçe öğretimi
}

Efecan KARAGÖL ${ }^{1}$

\section{Cihat Burak KORKMAZ}

APA: Karagöl, E.; Korkmaz, C. B. (2021). Ders kitabı ve bilimsel metin yazarlarının görüşlerine göre uluslararası öğrencilere akademik Türkçe öğretimi. RumeliDE Dil ve Edebiyat Araştırmalar Dergisi, (25), 208-230. DOI: 10.29000/rumelide.1032431.

$\ddot{O} \mathbf{z}$

Akademik Türkçe, Türkçenin bilimsel metinlerde ve akademik ortamlarda kullanılan hâlidir. Bu dersin nihai hedefi öğrencilerin akademik dil becerilerini geliştirmektir. Akademik Türkçe, daha çok uluslararası öğrencilerin lisans düzeyinde kullanılan Türkçeye uyum sağlamaları amacıyla Türkçe dil kursu sonrası almaları gereken bir ders olarak düşünülmektedir. Araştırmanın amacı, ders kitabı ve bilimsel metin yazarlarının uluslararası öğrenciler için yürütülen akademik Türkçe öğretimine (temel hedefler, öğretim programı, dersin verilme zamanı ve süresi, öğretici özellikleri, sözlük ve ders kitabı nitelikleri, disiplin ayrımı ve dersin zorunlu olması/olmaması durumuna) ilişkin görüşlerini incelemektir. Nitel durum çalışması olarak tasarlanan araştırmada akademik Türkçe öğretimine yönelik ders kitabı ve bilimsel metin hazırlayan yirmi bir yazardan yarı yapılandırılmış görüşme formuyla veriler toplanmıştır. İçerik analizi tekniğiyle veriler çözümlenmiştir. Araştırmada; akademik Türkçe dersine yönelik öğretim programı hazırlanmasının gerekliliği, bu öğretim programında temel hedefler ve kazanımların yanı sıra yöntem-teknik, ölçme-değerlendirme ve akademik söz varlığı listelerinin olması, dersin nihai olarak akademik dil becerilerini geliştirmeyi hedeflemesi, dersin ne zaman, kaç saat veya hafta ve kim tarafindan verileceğinin kesinleştirilmesi, ders materyallerinin öğretim programının ilke ve kazanımlarına göre hazırlanması, lisans öncesi verilecek genel akademik Türkçe dersinin fen, sosyal, eğitim ve sağlık bilimleri ayrımı gözetilerek, özel akademik Türkçe derslerinin de bölüm tasnifi yapılarak verilmesi, akademik Türkçe dersinin bütün uluslararası öğrencilere zorunlu olması sonuçlarına ulaşılmıştır.

Anahtar kelimeler: Akademik dil, akademik dil becerileri, akademik Türkçe, yabancı dil olarak Türkçe öğretimi

\section{Academic Turkish teaching to international students according to the views of textbook and scientific text writers}

\begin{abstract}
Academic Turkish is the Turkish language used in scientific texts and academic environments. The ultimate goal of this course is to develop students' academic language skills. The purpose of this research is to examine the views of textbook and scientific text writers on academic Turkish teaching (basic objectives, curriculum, teaching time and duration of the course, instructional features,
\end{abstract}

Doç. Dr., Zonguldak Bülent Ecevit Üniversitesi, Ereğli Eğitim Fakültesi, Türkçe Eğitimi ABD (Zonguldak, Türkiye), efecankaragol@gmail.com, ORCID ID: 0000-0003-0331-8009 [Araştırma makalesi, Makale kayıt tarihi: 10.11.2021kabul tarihi: 20.12.2021; DOI: 10.29000/rumelide.1032431]

Dr., Ankara Yıldırım Beyazıt Üniversitesi, Dil Eğitimi Uygulama ve Araştırma Merkezi (Ankara, Türkiye), cbkkrkmz@gmail.com, ORCID ID: oooo-00o3-4383-3443

Adres $\mid$ Address

RumeliDE Dil ve Edebiyat Araşturmalar Dergisi $\quad$ RumeliDE Journal of Language and Literature Studies

Osmanağa Mahallesi, Mürver Çiçeği Sokak, No:14/8 Osmanağa Mahallesi, Mürver Çiçeği Sokak, No:14/8

Kadıköy - İSTANBUL / TÜRKIYE 34714 Kadıköy - ISTANBUL / TURKEY 34714

e-posta: editor@rumelide.com e-mail: editor@rumelide.com,

tel: +90 505 7958124, +90 2167730616 phone: +90 505 7958124, +90 2167730616 
dictionary and coursebook qualifications, disciplinary distinction, and compulsory/non-compulsory course). In the research, which was designed as a qualitative case study, data were collected through semi-structured interview form from twenty-one authors who prepared a textbook and scientific text for academic Turkish teaching. Data were evaluated with inductive content analysis. In the research; The necessity of preparing a curriculum for the academic Turkish course, the main objectives and achievements in this curriculum, as well as the list of method-technical, measurement-evaluation and academic vocabulary, the course aims to develop academic language skills, determining when, how many hours or weeks the course will be given and by whom, preparation of course materials according to the principles and achievements of the curriculum, taking into account the distinction between science, social, education and health sciences of the general academic Turkish course to be given before the undergraduate degree, special academic Turkish courses can be classified into departments It has been concluded that the academic Turkish course is compulsory for all international students.

Keywords: Academic language, academic language skills, academic Turkish, teaching Turkish as a foreign language

\section{Giriş}

Akademik Türkçe dersinin nihai hedefi öğrencilerin akademik dil becerilerini geliştirmektir. Daha çok uluslararası öğrencilerin yükseköğretime uyum sağlaması amacını ve bu düzeyde gerekli olan akademik dil becerilerini öğrencilere kazandırma niteliğini taşımaktadır ancak söz konusu dersin öğretim programı eksikliği, verilme zamanı ve süresi, öğretici özellikleri, materyalleri, sınıfların disiplinlere (sosyal, eğitim, fen, sağlık bilimleri) göre oluşturulmaması ve dersin zorunlu olması/olmaması gibi sorunlar hâlâ çözülebilmiş değildir. Belirtilen sorunların çözümüne katkı sunmak adına akademik Türkçe ders kitabı yazarları ile bu alana yönelik bilimsel metin üretenlerin görüşleri önem arz etmektedir.

İkinci/yabancı dil olarak Türkçe öğretimi, Diller İçin Avrupa Ortak Başvuru Metni (CEFR) doğrultusunda öğrencilerin dört temel dil becerisini geliştirmeyi amaçlar. Bu amaca ulaşmak için süreç temelli bir öğretim esas alınır. İstenilen seviyeye ulaşılabilmesi için süreç içerisinde geri dönütler alınır ve bu geri dönütler neticesinde ilerlemeler yapılır. Öğrenilenlerin unutulmasının önüne geçmek ve öğrenilenleri pekiştirmek amacıyla öğretim programları içerisinde daha önceki öğrenmelere yer verilir (İltar, 2021: 130).

Türkiye’de lisans ve lisansüstü öğrenim öncesi uluslararası öğrencilerden Türkçe yeterliklerini belgelemeleri istenir. Üniversiteler genellikle C1 düzeyinde Türkçe bilmeyi uluslararası öğrencilere ön şart olarak koşar. Ancak literatürdeki araştırmalar, belirtilen düzeyde Türkçe bilmenin uluslararası öğrencilerin akademik başarıları açısından yeterli olmadığını, lisans öğrenimleri sırasında bu öğrencilerin çeşitli sorunlarla karşılaştıklarını ortaya koymuştur. Örneğin Demir (2017) ve Konyar (2019), uluslararası öğrencilerin akademik Türkçe ihtiyaçlarını ve bu bağlamda yaşanan sorunları saptamıştır. Ayrıca bu öğrencilerin akademik dil becerilerinde sorunlar yaşadıklarını, bu sorunların derse yönelik akademik başarıyı etkilediğini çeşitli üniversitelerde görev yapan öğretim üyeleri dile getirmektedir. Mevcut sorunun çözülmesi, akademik dil öğretimini amaçlayan nitelikli bir akademik Türkçe dersinin verilmesini zorunlu kılmaktadır.

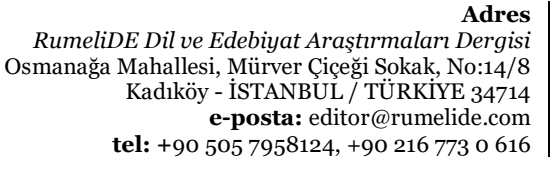

Adres

8

Address

RumeliDE Journal of Language and Literature Studies

Osmanağa Mahallesi, Mürver Çiçeği Sokak, No:14/8

Kadıköy - ISTANBUL / TURKEY 34714

e-mail: editor@rumelide.com,

phone: +90 5057958124 , +90 2167730616 
Academic Turkish teaching to international students according to the views of textbook and scientific text writers / E. Karagöl; C. B. Korkmaz (pp. 208-230)

Akademik dil; öğrencilerin üniversite eğitimlerine ve kariyerlerine hazırlanırken erişmesi, anlamlı bir şekilde ilgilenmesi ve sıkı akademik içeriğe ulaşması gereken dil olarak tanımlanabilir (Sato, 2011'den aktaran Feller, 2015). Akademik dil, akademik ortamlarda ve araştırmalarda kullanılır. Düz anlamlıdır ve kurgu yönü yoktur (Seyedi, 2020: 27). Uluslararası öğrencilere akademik dilin özelliklerini işlevsel olarak kazandırmak için anlama ve anlatma becerilerinin akademik bağlamda kullanılmasına yönelik içerikler sunmak gerekmektedir.

Standart Türkçenin yetkinlik gerektiren özel alt alanlarından biri de akademik Türkçedir. Bu alt alan, dili akademik bağlamda hem üretici hem de alıcı olarak kullanmayı gerektirir. Akademik dinleme/izleme ile okuma alıcı; akademik konuşma ile yazma üretici akademik dil kullanımını oluşturmaktadır. Akademik dinleme/izleme; sınıf başta olmak üzere çeşitli akademik ortamlarda öğrencilerin en çok ihtiyaç duyduğu alıcı dil becerisidir. Akademik konuşma; öğretmenle, danışmanla ya da sınıf arkadaşlarıyla iletişim kurma, ders ortamında soru sorma, sorulara cevap verme, grup çalışmalarında bulunma, tartışmalara katılma ve sunum yapma gibi durumlarda en çok ihtiyaç duyulan ve sıklıkla kullanılan becerilerden biridir (Göçen, 2020: 227). Akademik okuma, okurun akademik düzeyini yükseltmek amacıyla bilimsel makale, araştırma raporları, tezler, düşünce yazıları vb. türdeki metinler üzerinden gerçekleştirdiği okuma türüdür (Ülper, 2019: 19). Akademik yazma ise akademik bağlamdaki araştırmaların çeşitli türlerde raporlaştırılması sürecinde içerik, biçim, yazım ilkeleri, dil ve anlatım yönlerinden kendine has ilkeleri olan yazma alanıdır (Karagöl, 2018: 7).

Lisans ve lisansüstü düzeylerde alıcı ve üretici dil kullanımı bağlamında akademik Türkçeye duyulan ihtiyacın boyutları değişmektedir. Lisans düzeyinde bölüm dersiyle ilgili bir metni okuma, aranan bilgiyi metinde bulma, metnin konu, ana fikir ve yardımcı fikirlerini bulma, araştırma ödevi için kütüphane kataloglarını kullanma, işaretleyerek okuma; öğreticinin söylediklerini etkin dinleme, öğreticinin konuya giriş, konuyu açıklama ve örnekleme ifadelerini anlama, dinlerken not alma; konuya yönelik düşüncelerini ifade etme, dinlediklerinden hareketle soru sorma, sınıf içi tartışmalara katılma, ödev sunumu yapma; ödev raporu yazma, etkili giriş paragrafı oluşturma ve ders kitabına açıklayıcı notlar yazma gibi dil becerilerine yönelik yeterliklere sahip olması öğrencilerden beklenir. Lisansüstü düzeyde ise bildirili konuşmaları takip etme, akademik tartışmalardaki tez ve karşı tezleri belirleme; dinledikleri/izlediklerinden hareketle sorular sorma, teknolojik araçları kullanarak bildiri sunma, tartışmalarda tez/karşı tez ileri sürme; araştırma konusuyla ilgili literatüre ulaşma, eleştirel okuma, analitik okuma, disiplinler arası okuma, akademik metinlerdeki cümle, paragraf ve metin yapıları hakkında bilgi sahibi olma; akademik metinlerin giriş, bulgu ve sonuç bölümlerini yazma, akademik söz varlığı ve dil bilgisinden yararlanma, öğrencilerin sahip olması gereken yetkinlikler olarak düşünülebilir. Ayrıca -Demir'in (2020: 3-11) belirttiği üzere- akademik Türkçenin akademik dil, terim, akademik sözcük, düz anlam, betimleyici ve bilgilendirici üslup, kanıtlama, belli dil bilgisi yapılarının tercihi ve kurgu gibi çeşitli özellikleri vardır. Söz konusu özellikler, uluslararası öğrencilerin lisans ve lisansüstü düzeylerde ihtiyaç duyduğu diğer yetkinlikler olarak ifade edilebilir.

Akademik Türkçe dersinin öğretimine yönelik çeşitli sorunlar mevcuttur. Bu sorunlar, derse yönelik "ne"yin "ne zaman" ve "nası" yapılacağının belirsiz olmasından kaynaklanmaktadır. Diğer bir ifadeyle dersin öğretim programının ve temel hedeflerinin net bir şekilde belirtilmemiş olması, verilme zamanı ve süresinin belirsiz olması, dersi yürütecek öğreticinin belirsizliği, kullanılabilecek sözlük ve ders kitabının niteliklerine yönelik ölçütlerin yoksunluğu, dersin disiplin ayrımına göre verilmesi/verilmemesi ve zorunlu olması/olmaması gibi hususlar açıklığa kavuşturulmalıdır. Memiş’in (2021: 111) belirttiği gibi öğretim programı hazırlanmadığı sürece akademik Türkçe öğretiminin kalitesi ve öğrenenlerin bu husustaki yeterliliği sorun olmaya devam edecektir.

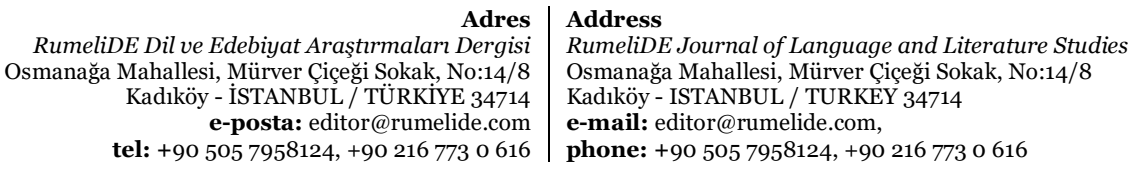


Akademik Türkçe dersi, Yurt Dışı Türkler ve Akraba Topluluklar Başkanlığı'nın (YTB) desteğiyle 20162017 eğitim öğretim yılından itibaren TÖMER müfredatlarına dâhil edilmiştir (Gürata \& Kurt, 2020: 63) ve günümüzde YTB’nin "Türkiye Burslusu” öğrencileri için verilmeye devam edilmektedir. Ayrıca Yükseköğretim Kurulu Başkanlığının (YÖK) 22.03.2019 tarihli ve 75850160-302.01.02-E.20764 sayılı yazısıyla akademik Türkçe dersi seçmeli olarak fakülteler bünyesinde de verilmektedir. Belirtilen yazıda dersin açılma gerekçesiyle ilgili “Üniversitelerimizde Türkçe programlarda öğrenime başlayan yabancı öğrenciler için Türkçe hazırlık sınıfında aldıkları eğitimin onların özellikle sosyal alanlardaki programlarda başarı düzeylerini yüksek tutabilmeleri için yeterli olmadığı, eğitimleri sırasında Türkçe bilgi düzeylerini geliştirmeye yönelik olarak Akademik Türkçe dersleri almalarının yararlı olabileceği düşünülmektedir.” vurgusu dikkat çekmektedir. Ancak YÖK’ün resmî yazısına rağmen bir önceki paragrafta belirtilen sorunların çözüme kavuşmadığı bilinmektedir.

"Akademik Türkçe”, “akademik dil”, “akademik dinleme/izleme”, “akademik konuşma”, “akademik okuma" ve "akademik yazma” anahtar sözcükleriyle yapılan tarama sonucunda uluslararası öğrencilere akademik Türkçe öğretimiyle ilgili çeşitli araştırmaların olduğu belirlenmiştir: Akademik okuryazarlık öğretimi (Ekmekçi, 2017), lisansüstü eğitim gören veya mezun öğrencilerin akademik yazma sorunları ile ihtiyaçları (Seyedi, 2019), akademik ve teknik söz varlığı (Dolmacı, 2015, Tüfekçioğlu, 2018), uluslararası öğrencilerin akademik Türkçe ihtiyaçları, bu bağlamda yaşanan sorunlar ve örnek ders içerikleri (Demir, 2017; Konyar, 2019), akademik Türkçe öğretimi amacıyla hazırlanan ders kitapları (Çiftler \& Aytan, 2019; Demir, 2020, Deniz \& Karagöl, 2019; Göçen, 2021, Moralı, 2019, Sallabaş \& Korkmaz, 2019), akademik Türkçe dersinin önemi (Yahşi Cevher \& Güngör, 2015), lisansüstü öğrencilerin akademik Türkçe özyeterlikleri (Hasırcı Aksoy, 2021), akademik Türkçe dersi alan öğrencilerin yazma sorunları (Demiriz \& Okur, 2019, Er \& Üstten, 2017, Uslu Üstten \& Yılmaz, 2020) ve öğrencilerin okuduğunu özetleme becerisi (Özcan, Eroğlu \& Demirdöven, 2018). Belirtilen araştırmalarda akademik Türkçeye ilişkin ders kitabı hazırlayan ve bilimsel metin üreten yazarların görüşlerine yer verilmemiştir. Bu derse ilişkin materyal üreten ve bilimsel araştırma yapan yazarların öğretim programı, temel hedefler, dersin verilme zamanı ve süresi, öğretici özellikleri, sözlük ve ders kitabı nitelikleri, disiplin ayrımı ve dersin zorunlu olması/olmaması durumlarına ilişkin görüşlerini ortaya koyması bakımından mevcut araştırma diğerlerinden farklılaşmaktadır. Araştırmanın amacı, ders kitabı ve bilimsel metin yazarlarının uluslararası öğrenciler için yürütülen akademik Türkçe öğretimine (temel hedefler, öğretim programı, dersin verilme zamanı ve süresi, öğretici özellikleri, sözlük ve ders kitabı nitelikleri, disiplin ayrımı ve dersin zorunlu olması/olmaması durumlarına) ilişkin görüşlerini incelemektir. Belirtilen amaca yönelik derinlemesine tespitler yapmak amacıyla aşağıdaki alt problemler belirlenmiştir:

1. Ders kitabı ve bilimsel metin yazarlarının görüşlerine göre akademik Türkçe dersinin temel hedefleri neler olmalıdır?

2. Ders kitabı ve bilimsel metin yazarları akademik Türkçe öğretimine yönelik bir öğretim programının gerekliliği hakkında neler düşünmektedir? Böyle bir öğretim programının içeriği nasıl olmalıdır?

3. Ders kitabı ve bilimsel metin yazarları akademik Türkçe dersinin hangi düzeyden itibaren kaç ders saati ve hafta olarak verilmesini önermektedir?

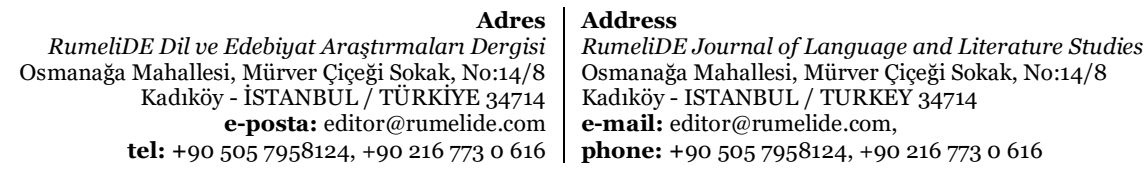

Adres
RumeliDE Dil ve Edebiyat Araşttrmaları Dergisi (añ tel: +90 505 7958124, +902167730616 
4. Ders kitabı ve bilimsel metin yazarları akademik Türkçe dersini kim veya kimlerin vermesini önermektedir? Akademik Türkçe dersi verecek öğreticilerin mesleki gelişimi için neler yapılmalıdır?

5. Ders kitabı ve bilimsel metin yazarlarının akademik Türkçe dersi kapsamında söz varlı̆̆ı öğretimi için önerdiği dijital veya basılı sözlükler nelerdir? Bu derse yönelik hazırlanmış müstakil bir sözlüğün özellikleri neler olmalıdır?

6. Ders kitabı ve bilimsel metin yazarlarına göre akademik Türkçe dersleri için öğrenme ortamında kullanılabilecek ders materyalleri (ders kitabı ve diğer materyaller) nelerdir? Bu ders materyalleri hangi özelliklere sahip olmalıdır?

7. Ders kitabı ve bilimsel metin yazarları akademik Türkçe derslerinde sosyal bilimler, fen bilimleri vb. ayrımının yapılması/yapılmaması hakkında neler düşünmektedir? Öğrencilerin farklılaşan mesleki gelişim alanları karşısında nasıl bir yol izlenmelidir?

8. Ders kitabı ve bilimsel metin yazarları YTB burslusu öğrencilere akademik Türkçe dersinin zorunlu olması, diğer öğrencilere bu dersin zorunlu olmaması hakkında neler düşünmektedir?

Ders kitabı ve bilimsel metin yazarlarının akademik Türkçenin sorunlarına ilişkin görüşlerini değerlendiren bir çalışmanın literatürde olmaması araştırmanın önemi olarak ifade edilebilir. Bunun yanı sıra araştırmada ulaşılan bulguların akademik Türkçeye yönelik mevzuat değişikliği ve öğretim programı hazırlanması gibi hususlarda katkı sağlayacağı düşünülebilir.

\section{Yöntem}

Bu başlık altında araştırmanın deseni, çalışma grubu, verilerin toplanması ve analiziyle ilgili bilgiler yer almaktadır.

\section{Araştırmanın deseni}

Uluslararası öğrencilere akademik Türkçe öğretimine yönelik ders kitabı ve bilimsel metin yazarlarının görüşlerini incelemeyi amaçlayan bu araştırma nitel olarak tasarlanmıştır. Seggie ve Bayyurt'un (2015: 16) ifade ettiği gibi nitel araştırma, nicel araştırmaların aksine, gelişen ve değişen dünyanın ve oluşan yeni anlayışların ve beraberinde gelen sorun ve mücadelelerin detaylı bir şeklide anlaşılmasına olanak sağlar. Nitel araştırmalarda birtakım araştırma desenleri mevcuttur. Eylem araştırması, fenomenoloji, durum çalışması, etnografya, anlatı araştırması ve gömülü teori nitel araştırmaların desenlerindendir (Saban \& Ersoy, 2019). Bu araştırma nitel durum çalışması olarak desenlenmiştir. Creswell (2013: 97) durum çalışmasını "Araştırmacının gerçek yaşam, güncel sınırlı bir sistem (bir durum) ya da belli bir zaman içerisindeki çoklu sınırlandırılmış sistemler (durumlar) hakkında çoklu bilgi kaynakları (örneğin gözlemler, mülakatlar, görsel-işitsel materyaller, dokümanlar ve raporlar) aracıllğıyla detaylı ve derinlemesine bilgi topladığı, bir durum betimlemesi ya da durum temaları ortaya koyduğu nitel bir yaklaşım.” olarak tanımlamıştır. Bu araştırmada çoklu bilgi kaynaklarından görüşme yoluyla derinlemesine bilgilere ulaşmak amacıyla durum çalışması deseni kullanılmıştır.

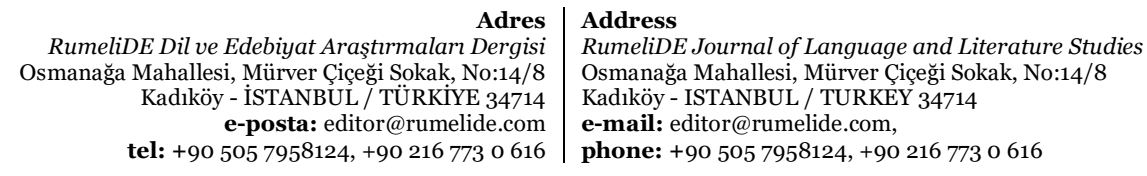




\section{Çalışma grubu}

Araştırmanın çalışma grubunu uluslararası öğrencilere akademik Türkçe öğretimine yönelik ders kitabı ve bilimsel metin hazırlayan yirmi bir yazar oluşturmaktadır. Katılımcı özelliklerine aşağıda yer verilmiştir:

Tablo 1. Çalışma grubundaki yazarlara ilişkin bilgiler

\begin{tabular}{|c|c|c|c|c|c|c|c|}
\hline $\begin{array}{l}\text { Katılımcı } \\
\text { kodu }\end{array}$ & $\begin{array}{l}\text { Öğrenim } \\
\text { durumu }\end{array}$ & $\begin{array}{l}\text { Uluslararası } \\
\text { öğrencilere } \\
\text { Türkçe } \\
\text { öğretme } \\
\text { durumu }\end{array}$ & $\begin{array}{l}\text { Uluslararası } \\
\text { öğrencilere } \\
\text { akademik } \\
\text { Türkçe dersi } \\
\text { verme } \\
\text { durumu }\end{array}$ & $\begin{array}{l}\text { Katılıme } \\
\text { kodu }\end{array}$ & $\begin{array}{l}\text { Öğrenim } \\
\text { durumu }\end{array}$ & $\begin{array}{l}\text { Uluslararası } \\
\text { öğrencilere } \\
\text { Türkçe } \\
\text { öğretme } \\
\text { durumu }\end{array}$ & $\begin{array}{l}\text { Uluslararası } \\
\text { öğrencilere } \\
\text { akademik } \\
\text { Türkçe dersi } \\
\text { verme } \\
\text { durumu }\end{array}$ \\
\hline $1 \mathrm{~K}$ & Doktora & Evet & Hayır & $12 \mathrm{~K}$ & Doktora & Evet & Evet \\
\hline $2 \mathrm{~K}$ & Doktora & Evet & Evet & $13 \mathrm{~K}$ & Doktora & Evet & Hayır \\
\hline $3 \mathrm{~K}$ & Doktora & Evet & Hayır & $14 \mathrm{~K}$ & Doktora & Evet & Evet \\
\hline $4 \mathrm{~K}$ & Doktora & Evet & Evet & $15 \mathrm{~K}$ & $\begin{array}{l}\text { Yüksek } \\
\text { lisans }\end{array}$ & Evet & Evet \\
\hline $5 \mathrm{~K}$ & Doktora & Evet & Evet & $16 \mathrm{~K}$ & Doktora & Evet & Evet \\
\hline $6 \mathrm{~K}$ & $\begin{array}{l}\text { Yüksek } \\
\text { lisans }\end{array}$ & Evet & Evet & $17 \mathrm{~K}$ & Doktora & Evet & Evet \\
\hline $7 \mathrm{~K}$ & Doktora & Evet & Hayır & $18 \mathrm{~K}$ & Doktora & Evet & Hayır \\
\hline $8 \mathrm{~K}$ & $\begin{array}{l}\text { Yüksek } \\
\text { lisans }\end{array}$ & Evet & Evet & $19 \mathrm{~K}$ & Doktora & Evet & Evet \\
\hline $9 \mathrm{~K}$ & Doktora & Evet & Evet & $20 \mathrm{~K}$ & Doktora & Evet & Hayır \\
\hline $10 \mathrm{~K}$ & $\begin{array}{l}\text { Yüksek } \\
\text { lisans }\end{array}$ & Hayır & Hayır & $21 \mathrm{~K}$ & Doktora & Evet & Evet \\
\hline $11 \mathrm{~K}$ & Doktora & Evet & Evet & & & & \\
\hline
\end{tabular}

Çalışma grubunun belirlenmesinde amaçlı örnekleme yöntemlerinden ölçüt örnekleme tekniği kullanılmıştır. Katılımcıların en az \%65'inin doktora mezunu olması, uluslararası öğrencilere Türkçe ve akademik Türkçe öğretmesi ve \%10o'nün akademik Türkçeye yönelik ders kitabı veya bilimsel metin üretmesi ölçütleri dikkate alınmıştır. Yukarıdaki tabloda yer alan bilgilere göre katılımcıların \%80’i doktora \%20'si yüksek lisans mezunudur. \%95 oranında katılımcı uluslararası öğrencilere Türkçe öğretmişken katılımcıların \%65’i bu öğrencilere akademik Türkçe dersi vermiştir. Araştırmada yazar isimleri “ $1 \mathrm{~K}, 2 \mathrm{~K}, 3 \mathrm{~K} . .$. ” biçiminde kodlanmıştır.

Araştırmanın katılımcı sayısı yirmi bir ile sınırlandırılmıştır. Yıldırım ve Şimşek’in (2008: 115) belirttiği üzere araştırmaya katılanlardan toplanacak verinin miktarı arttıkça örnekleme dâhil edilmesi gereken bireylerin sayısı azalmaktadır. Bu araştırmada ulaşılan veriler yeterli olduğu için (bk. Verilerin Toplanması) belirtilen sayıda yazar ile görüşülmüştür. Araştırma için Zonguldak Bülent Ecevit Üniversitesi İnsan Araştırmaları Etik Kurulundan 38561 sayılı belge ile gerekli izinler alınmıştır.

\section{Verilerin toplanması}

Nitel araştırmalarda veri toplama yöntemi olarak görüşme, gözlem ve dokümanlar kullanılır. Bu araştırmanın veri kaynağını yazar görüşleri oluşturduğu için araştırmada görüşme yöntemine

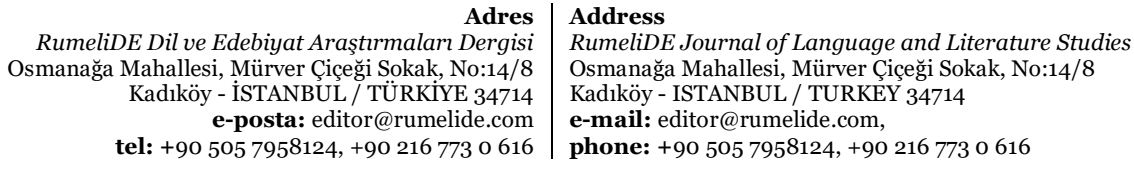


başvurulmuştur. Görüşme, en az iki kişi arasında sözlü olarak sürdürülen bir iletişim sürecidir. Görüşme, araştırmada cevabı aranılan sorular çerçevesinde ilgili kişilerden veri toplama şeklinde ifade edilebilir. Görüşme belirli bir araştırma konusu veya bir soru hakkında derinlemesine bilgi sağlar (Büyüköztürk, Çakmak, Akgün, Karadeniz ve Demirel, 2008: 158).

Veri toplama aracı olarak yarı yapılandırılmış görüşme formu kullanılmıştır. İki bölümden oluşan formun birinci bölümünde araştırmacıların öğrenim durumu, TÖMER deneyimi ve akademik Türkçe dersi verme durumları; ikinci bölümünde ise alt problemlere ilişkin sekiz soru yer almaktadır. Araştırmacılar tarafından hazırlanan taslak soru metinleri yabancı dil olarak Türkçe ve akademik Türkçe öğretimine ilişkin bilimsel araştırmaları bulunan üç alan uzmanına gönderilmiştir. Alan uzmanlarından gelen dönütlerden sonra ön uygulama yapılarak sorulara son hâli verilmiştir. Araştırmanın görüşme soruları şöyledir:

1. Uluslararası öğrencilere verilen "Akademik Türkçe” dersinin temel hedefleri neler olmalıdır?

2. Akademik Türkçe öğretimine yönelik bir öğretim programının gerekliliği hakkında neler düşünüyorsunuz? Böyle bir öğretim programı neleri içermelidir/hangi ihtiyaçları karşılamalıdır?

3. Akademik Türkçe dersi hangi düzeyden itibaren kaç ders saati ve hafta olarak verilmelidir?

4. Akademik Türkçe dersini kim veya kimler vermelidir? Bu dersi verecek öğreticilerin mesleki gelişimi için neler yapılmalıdır?

5. Akademik Türkçe dersi kapsamında söz varlığı öğretimi için önerebileceğiniz dijital veya basılı sözlükler nelerdir? Bu derse yönelik hazırlanmış müstakil bir sözlüğün özellikleri neler olmalıdir?

6. Akademik Türkçe dersleri için öğrenme ortamında kullanılabilecek ders materyalleri (ders kitabı ve diğer materyaller) nelerdir? Bu materyaller hangi özelliklere sahip olmalıdır?

7. Akademik Türkçe derslerinde sosyal bilimler, fen bilimleri vb. ayrımının yapılması/yapılmaması hakkında neler düşünüyorsunuz? Öğrencilerin farklılaşan mesleki gelişim alanları karşısında nasıl bir yol izlenmelidir?

8. YTB burslularına akademik Türkçe dersi zorunlu olmasına rağmen üniversiteye devam eden diğer uluslararası öğrencilere bu dersin zorunlu olmaması hakkında düşünceleriniz nelerdir?

Araştırmanın geçerlik ve güvenirlik çalışmaları için alan uzmanı görüşleri ve ön uygulama dışında bazı stratejilere başvurulmuştur. Görüşme sorularında kişisel yorum ve yanlı ifadelerden kaçınılmıştır. Görüşmecilere soruları yanıtlamaları için yeterli zaman verilmiş̧ir. Veriler olduğu gibi çözümlenmiş, araştırmacılar birbirinden bağımsız olarak kodlama yapmıştır. Kodlayıcılar arası uyumun hesaplanmasında Miles ve Huberman (2015) formülünden yararlanılmıştır. Uyum yüzdesi o,89 olarak bulunmuştur. Bu uyum \%70'ten fazla olduğu (Tavşancıl \& Aslan, 2001) için yapılan içerik analizi güvenilir kabul edilmiştir. Araştırma sürecinin ayrıntılı biçimde raporlaştııılmasının yanı sıra kodlara ilişkin doğrudan alıntı yapılarak yazar görüşlerine yer verilmiştir.

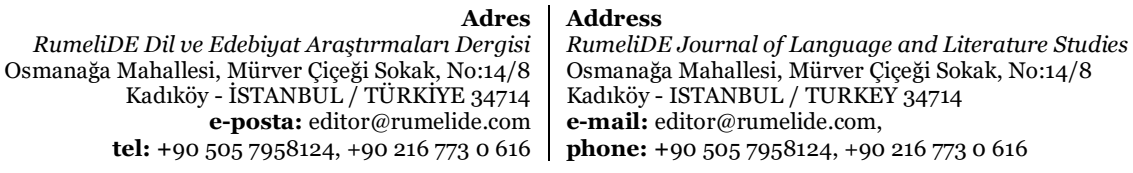


Verilerin toplanması aşamasında COVID-19 nedeniyle katılımcılarla yüz yüze görüşme gerçekleştirilmemiş, bunun yerine veriler dijital ortamda toplanmıştır. Microsoft Office Word programında Times New Roman yazı karakteri, 12 punto, 2,5 cm sayfa kenar boşlukları ve tek satır aralı̆̆ıyla yapılan yazma işleminden sonra 8249 sözcükten oluşan 20 sayfalık veriye ulaşılmıştır.

\section{Verilerin analizi}

Araştırmanın verileri içerik analizi tekniğiyle çözümlenmiştir. İçerik analizi, bir veya birçok metnin içindeki sözcüklerin, kavramların, temaların, deyimlerin, karakterlerin veya cümlelerin varlıklarını belirlemek ve onları sayıya dökmek için kullanılır (Kızltepe, 2015: 253-254). Araştırmanın alt problem cümleleri temaların oluşturulmasına yardımcı olmuştur. Bu nedenle temalar araştırma sürecinin başında belirlenmiştir. Araştırmanın kategori ve kodlarına çözümleme sürecinde ulaşılmıştır. Temalar tablo başlı̆̆ 1 olarak ifade edilmiştir. Kod, alt kategori, kategori ve sıklıklara (f) tablo içinde yer verilmiştir. Bazı tablolarda gerek görülmediği için alt kategorilere yer verilmemiştir. Tabloların deşifresi yapıldıktan sonra bazı katılımcıların görüşleri örnek olarak sunulmuştur. Katılımcıların herhangi bir görüşme sorusuna verdiği cevaplar birden fazla koda karşılık geldiği için bazı kodların sayısı katılımcı sayısından yüksek çıkmıştır.

\section{Bulgular}

Bu bölümde araştırmanın alt problem cümleleri doğrultusunda ulaşılan verilere (alt bulgulara) yer verilmiştir.

\section{Araştırmanın birinci alt problemine ilişkin bulgular}

Tablo 2. "Akademik Türkçe dersinin temel hedefleri” teması

\begin{tabular}{|c|c|c|c|}
\hline Kodlar & Alt Kategoriler & Kategoriler & $\mathrm{f}$ \\
\hline $\begin{array}{l}\text { Lisansüstü eğitim için alıcı ve üretici dil } \\
\text { yeterliklerinin kazandırılması }\end{array}$ & $\begin{array}{l}\text { Alıcı ve üretici dil } \\
\text { becerileri }\end{array}$ & \multirow{7}{*}{$\begin{array}{l}\text { Akademik dil } \\
\text { becerilerinin } \\
\text { kazandırılması }\end{array}$} & 4 \\
\hline Akademik metin türlerinin okunması/anlaşılması & \multirow{2}{*}{$\begin{array}{l}\text { Akademik anlama } \\
\text { becerileri }\end{array}$} & & 12 \\
\hline Akademik dinleme metinlerinin anlaşılması & & & 9 \\
\hline Akademik konuşma becerilerinin geliştirilmesi & \multirow{2}{*}{$\begin{array}{l}\text { Akademik anlatma } \\
\text { becerileri }\end{array}$} & & 14 \\
\hline Akademik yazma becerilerinin geliştirilmesi & & & 16 \\
\hline Teknolojiyi kullanarak bilimsel metin oluşturma & $\begin{array}{l}\text { Teknoloji destekli } \\
\text { akademik yazma }\end{array}$ & & 1 \\
\hline $\begin{array}{l}\text { Anlatım tekniklerinin (örneğin, açılklama, bilgi } \\
\text { verme, tartışma, ikna etme vs.) kazandırılması }\end{array}$ & Anlatma teknikleri & & 1 \\
\hline Akademik sözcük öğretimine yer verilmesi & \multirow{2}{*}{$\begin{array}{l}\text { Akademik ve teknik } \\
\text { söz varlığı }\end{array}$} & \multirow[t]{2}{*}{ Söz varlığı öğretimi } & 3 \\
\hline Teknik terimlerin öğretilmesi & & & 1 \\
\hline
\end{tabular}

Yukarıdaki tablo, akademik Türkçe dersinin temel hedeflerine ilişkin ders kitabı ve bilimsel metin yazarlarının görüşlerini içermektedir. Dokuz kod, altı alt kategori ve iki kategoriye ulaşılmıştır. Akademik yazma ( $\mathrm{f}=16)$ ve konuşma $(\mathrm{f}=14)$ becerilerinin geliştirilmesi, akademik metin türlerinin hem okuma ( $\mathrm{f}=12$ ) hem de dinleme ( $\mathrm{f}=9$ ) yoluyla anlaşılması ve akademik sözcük öğretimine yer verilmesi en çok ulaşılan kodlardır. Aşağıda katılımcı görüşlerine örnekler verilmiştir:

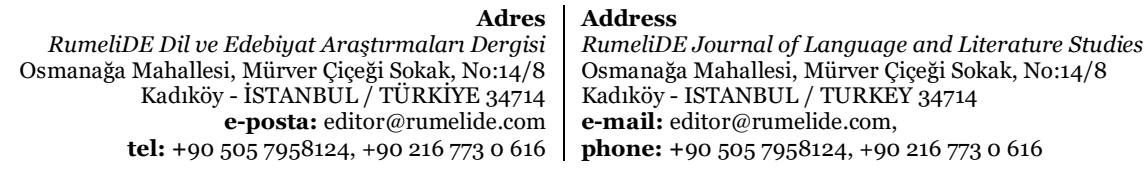


Academic Turkish teaching to international students according to the views of textbook and scientific text writers / E. Karagöl; C. B. Korkmaz (pp. 208-230)

İleri seviyede Türkçe öğrenmişöğrencileri, üniversitedeki ders ve sımı ortamına hazırlamak birinci ve en önemli hedef olmahdır. Yavaş yavaş konuşarak onlarm anlamadığı her cümleyi tekrar eden bir Türkçe öğretiminden huzh konuşan üniversite hocalarmın sözlerine yetişemeyen öğrencilerin ders kitaplarm okumakta ve anlamakta zorlandıkları bir gerçektir. Bir ayllk bir akademik Türkçe kursuyla jet hızıyla aradaki bu açı̆̆ı kapatmak mümkün olmasa da öğrencilerin yumuşak bir geçiş yapmalarma olanak sağlama hedef olmahdır. $(2 K)$

Akademik Türkçe dersleri ile uluslararası öğrencilerin ders kitapların ve dersleri anlamalarına, bilimsel araştırma yapmalarına ve bilimsel yazılar yazmalarna yardımcı olmak amaçlanmahdır. $(7 K)$

Akademik becerilerin anadilden ikinci/yabancı dile, hatta ikinci dilden ana dile etkileri / aktarmlarm incelemiş çalışmalar da mevcuttur. Bu yüzden öncelikle beceriler öğretilmelidir. (11K)

Lisansa başlayacak öğrenciler için bildiri, tez yazımına yönelik bir öğretim değil, bölüme gittiklerinde karşılaşacakları metinleri anlama, özetleme, not alma gibi becerilerin yanı sıra, yine ayn şekilde yazll anlatım ve akademik sunum yapabilme becerileri edindirilmelidir. (13K)

\section{Araştırmanın ikinci alt problemine ilişkin bulgular}

Tablo 3. “Uluslararası Öğrenciler İçin Akademik Türkçe Öğretim Programı” Teması

\begin{tabular}{|c|c|c|c|}
\hline Kodlar & Alt Kategoriler & Kategoriler & $\mathrm{f}$ \\
\hline Akademik söyleme yönelik kazanımlar & \multirow{4}{*}{$\begin{array}{l}\text { Akademik anlatma } \\
\text { becerileri }\end{array}$} & \multirow{14}{*}{ Programın özellikleri } & 3 \\
\hline Akademik konuşma ve yazma temelli kazanımlar & & & 4 \\
\hline Akademik paragraf yazma temelli kazanımlar & & & 1 \\
\hline Atıf yapma becerisine yönelik kazanımlar & & & 1 \\
\hline $\begin{array}{l}\text { Bütün dil becerilerini akademik bağlamda geliştirmeye } \\
\text { yönelik kazanımlar }\end{array}$ & $\begin{array}{l}\text { Akademik dil } \\
\text { becerileri }\end{array}$ & & 16 \\
\hline Teknik alanlara özgü söz varlığı listeleri & Söz varlığ & & 2 \\
\hline Öğretime ilişkin yöntem-teknik bilgisi & Yöntem ve teknik & & 1 \\
\hline Ölçme ve değerlendirme bilgisi & $\begin{array}{l}\text { Ölçme ve } \\
\text { değerlendirme }\end{array}$ & & 1 \\
\hline Bilimsel araştırma yöntemlerine yönelik kazanımlar & $\begin{array}{l}\text { Araştırma teknikleri } \\
\text { bilgisi }\end{array}$ & & 1 \\
\hline Dersin verilme zamanı bilgisi & \multirow[b]{2}{*}{ Zaman bilgisi } & & 1 \\
\hline $\begin{array}{l}\text { A2 düzeyinden itibaren bütün kurlara akademik Türkçe } \\
\text { kazanımlarının tanımlanması }\end{array}$ & & & 1 \\
\hline $\begin{array}{l}\text { Akademik Türkçe öğretim programının CEFR temelli } \\
\text { olması }\end{array}$ & \multirow[t]{2}{*}{ Programın kaynakları } & & 1 \\
\hline $\begin{array}{l}\text { Programın hazırlanmasında bölüm öğretim } \\
\text { elemanlarından görüş alınması }\end{array}$ & & & 1 \\
\hline $\begin{array}{l}\text { Ders kitabı yazarlarına, TÖMER'lere ve öğreticilere } \\
\text { rehberlik yapması }\end{array}$ & Kilavuzluk yapabilme & & 4 \\
\hline Sosyal, fen ve sağlık alanlarına göre ayrı içerikler & Disiplin ayrımı & $\begin{array}{l}\text { Alanlara göre öğretim } \\
\text { programı }\end{array}$ & 5 \\
\hline
\end{tabular}

Adres
RumeliDE Dil ve Edebiyat Araştırmaları Dergisi
Osmanağa Mahallesi, Mürver Çiçeği Sokak, No:14/8
Kadıköy - İSTANBUL / TÜRKIYE 34714
e-posta: editor@rumelide.com
tel: +90 505 7958124, +90 2167730616

Address

RumeliDE Journal of Language and Literature Studies

Osmanağa Mahallesi, Mürver Çiçeği Sokak, No:14/8

Kadıköy - ISTANBUL / TURKEY 34714

e-mail: editor@rumelide.com,

phone: +90 5057958124, +90 2167730616 
Tablo 3'te on beş kod, on alt kategori ve iki kategoriye yer verilmiştir. Katılımclların hepsi ( $\mathrm{f}=\mathbf{2 1})$ "Uluslararası Öğrenciler İçin Akademik Türkçe Öğretim Programı”na ihtiyaç olduğunu belirtmiştir. Akademik anlama ve anlatma becerileri ile söz varlığını geliştirmeyi hedeflemesi, öğretime ilişkin yöntem ve teknikleri, ölçme ve değerlendirme açıklamalarını içermesi, araştırma teknikleri bilgisine yer vermesi, zaman bilgisinin olması, CEFR ve uzman görüşüne dayanması, ders kitabı yazarlarına ve öğreticilere kılavuzluk yapabilmesi ve sosyal, fen, sağlık bilimleri gibi disiplin ayrımını içermesi söz konusu öğretim programından beklenmektedir. Aşağıda katılımcı görüşlerine örnekler verilmiştir:

Türkiye'de çalş̧an akademisyenlerin önemli bir bölümü dil öğretimi konusunda yeterli bilimsel olgunluğa sahip olmadan eser üretmeyi, boşlukları doldurmayı, açllan derslere hitap edebilecek kitaplar yazmayı seviyorlar. Bu nedenle öğrencilerimize amacı, hedefi, yöntemi, bilimsel temeli belli olmayan, çoğu zaman hızl ve özensiz üretilmiş eğitim materyalleri sunmak zorunda kalıyoruz. Öğretim programı geliştirmek bu sorunları gidermek için bir çözüm yolu olabilir. Türkiye bağlamında düşünüldüğ̈̈nde hem ders kitabı hazırlayıcılara hem Türkçe öğretim merkezlerine hem de akademik Türkçe dersini veren öğreticilere birçok katkı sağlayabilir. Hem ders içeriklerinin yapılandırılmasını hem de etkili bir şekilde değerlendirilmesini kolaylaştırabilir. (1K)

Ders veren veya verecek olan öğretim elemanları için bir kılavuz /rehber olacağını düşünüyorum. Çünkü akademik Türkçe dersleri genelde kurumlar tarafindan yazılan akademik Türkçe kitaplarndaki metinlerin okutulması, dinleme metinlerinin uygulanması olarak algılanmaktadır. Oysa öğretim programmın dersi veren öğretmenler için yönlendirici olacağım düşünüyorum. Program içeriği için önce ihtiyaç analizi belirlenmelidir. Program okuma, dinleme yazma ve konuşma becerileri özelinde öğrencilerin eğitim görecekleri alan (sosyal, fen, sağllk) ihtiyaçları doğrultusunda hazrrlanmalıdir. $(7 K)$

Böyle bir program gereklidir. Öğrencilerin en çok ihtiyaç duyduğu alanlarm eğitimini kapsamahdır. Yapılan ihtiyaç analizi çalışmalarında akademik yazma bunları başında gelmektedir. (8K)

İlk soruda da değindiğim gibi program öğrencilerde akademik üslubun oluşmasına katkı sağlamah, alanına, bölümüne ait konuları, temel kavramları anlamasına olanak sağlamalıdır. (9K)

Akademik Türkçe yeterlilikleri dil becerileri açısından tanımlanmalı. Bu tanımlamalar A2'den itibaren başlanmal ve tüm kur sürecine yayılmahdır. Bu programda öğrencilerin akademik ortamlardaki dili anlama ve anlatma gereksinimleri üzerine yoğunlaşlmalıdır. (2OK)

\section{Araştırmanın üçüncü alt problemine ilişkin bulgular}

Tablo 4. "Akademik Türkçe dersinin verilme zamanı ve ders saati" teması

\begin{tabular}{|c|c|c|}
\hline Kodlar & Kategoriler & $\mathrm{f}$ \\
\hline B2 düzeyinden itibaren & \multirow{7}{*}{ Dersin verilme zamanı } & 6 \\
\hline Lisans öğrenimi sırasında destekleyici eğitim biçiminde & & 2 \\
\hline Lisansüstü öğrenciler için özelleştirilmiş akademik Türk & & 3 \\
\hline C1 sonrası & & 10 \\
\hline $\mathrm{C} 1$ düzeyinde & & 3 \\
\hline En geç yüksek lisans öncesi & & 1 \\
\hline B1 sonrası & & 2 \\
\hline $\begin{array}{r}\text { Adres } \\
\text { RumeliDE Dil ve Edebiyat Arassttrmaları Dergisi } \\
\text { Osmanağa Mahallesi, Mürver Ciçeği Sokak, No:14/8 } \\
\text { Kadlköy - İSTANBUL / TÜRKIYY 34714 } \\
\text { e-posta: editor@rumelide.com } \\
\text { tel: +90 505 7958124, +90 216 773 } 0616\end{array}$ & $\begin{array}{l}\text { Address } \\
\text { RumeliDE Journal of Language and Literature Studies } \\
\text { Osmanağa Mahallesi, Mürver Ciçeği Sokak, No:14/8 } \\
\text { Kadı̈öy - ISTANBUL / TURKEY } 34714 \\
\text { e-mail: editor@ rumelide.com, } \\
\text { phone: +90 505 7958124, +90 } 216773 \text { o } 616\end{array}$ & \\
\hline
\end{tabular}




\begin{tabular}{lll}
\hline En az 150 ders saati & & 1 \\
\hline En az 180 ders saati & Ders saati & 1 \\
\hline İki dönem boyunca haftada 25 ders saati & 1 \\
\hline İki ay boyunca günde 3-4 ders saati & 1 \\
\hline En az 112 ders saati & 1 \\
\hline Sekiz hafta boyunca haftada 20 ders saati & 1 \\
\hline C1 kurunun üçte birinin akademik Türkçe olması & 1 \\
\hline İki dönem boyunca haftada en az 3 ders saati & 1 \\
\hline Haftada en az 2-3 gün üçer ders saati & 1 \\
\hline Sekiz hafta boyunca haftada 25 ders saati & 1 \\
\hline Bir dönem boyunca & & 1 \\
\hline
\end{tabular}

Tablo 4’te akademik Türkçe dersinin verilme zamanı ve ders saati temasına yönelik on sekiz kod ve iki kategoriye yer verilmiştir. $\mathrm{C} 1$ sonrası $(\mathrm{f}=10), \mathrm{B} 2$ düzeyinden itibaren $(\mathrm{f}=6)$, lisansüstü öğrenciler için özelleştirilmiş akademik Türkçe dersi $(\mathrm{f}=3)$ ve $\mathrm{C} 1$ düzeyinde $(\mathrm{f}=3)$ dikkat çeken bulgulardır. Ders saati kategorisinde katılımcılar birbirinden farklı görüşlere yer vermiştir. Sadece ders saati belirtenlerin yanı sıra bir dönem veya iki dönem boyunca bu dersin verilmesini savunan katılımcılar mevcuttur. Aşağıda katılımcı görüşlerine örnekler verilmiştir:

Akademik Türkçe dersinin lisans eğitimi öncesinde B2 düzeyinden itibaren verilmesi gerektiğini düşünüyorum. Ayrıca lisans strasında da destekleyici akademik Türkçe dersleri verilebilir. Lisans sonrasında ise Yüksek Lisans ve Doktora öğrencileri için bilimsel metin üretme, bilimsel metni anlama/kavrama, bilim okuryazarlı̆̆ kazanma, Türkçenin bilimsel söylemini tanıma vb. konularda daha ileri ve özelleştirilmiş akademik Türkçe dersleri verilebilir. (1K)

Öğrencilerin lisans, yüksek lisans veya doktora eğitimlerine başlamadan önce akademik Türkçe dersi almalarn gerektiğini düşünüyorum. Bunun için yinelemek istiyorum. İhtiyaç analizi çıkarmak gerekir. Gerekirse gözlem, görüşme veya anketler uygulanabilir. Günde 3-4 saat olmak koşulu ile iki ay sürecek bir program hazırlanabilir. $(7 \mathrm{~K})$

Lisansla birlikte verildiğinde, öğrenci bölüm derslerinde sıkıntı yaşamakta olacağı için akademik Türkçe dersini daha dikkatli takip edecektir. Birlikte verildiği durumda, haftada en az 4 saat, toplamda en az 112 saat olmahdır. Lisansüstü eğitim alacak öğrencilere ise, akademik Türkçe dersi lisansüstü dersler başlamadan önce verilmelidir. (8K)

C1 kurundan sonra haftada 20 saat olmak üzere 8 hafta verilmelidir. Lisans eğitimine başlamadan önce akademik Türkçe dersinin verilmesi öğrencinin daha donanıml bir şekilde lisans eğitimine başlamasını sağlayacaktır. (1oK)

Ortak Avrupa Çerçeve Metni’ne göre (2020) akademik dil C1 düzeyi kazanımları arasında yer alyyor. $B u$ nedenle bence $C 1$ düzeyinde yer almahdır. Bence lisans öncesinde verilmelidir. Normal ders programlarna ilave olarak eğer örneğ in C1 için toplam saatleri 120 saat ise örneğin, bunun 40 saati akademik Türkçe dersine ayrlabilir. (12K)

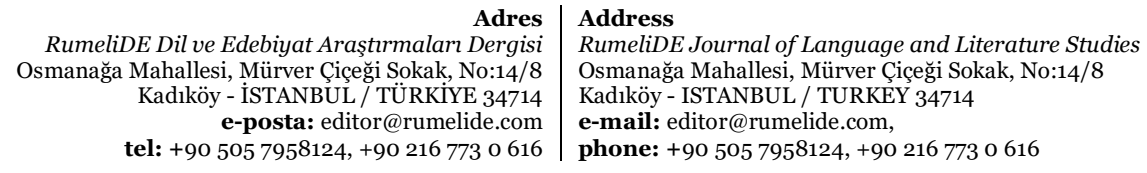




\section{Araştırmanın dördüncü alt problemine ilișkin bulgular}

Tablo 5. "Akademik Türkçe dersi için öğretici” teması

\begin{tabular}{|c|c|c|c|}
\hline Kodlar & Alt Kategoriler & Kategoriler & $\mathrm{f}$ \\
\hline TÖMER'lerdeki öğretim görevlileri & \multirow{4}{*}{ Öğrenim durumuna göre } & \multirow{7}{*}{ Öğretici özellikleri } & 7 \\
\hline En az yüksek lisans mezunu öğreticiler & & & 2 \\
\hline Doktora mezunu öğreticiler & & & 4 \\
\hline Fakültelerdeki öğretim üyeleri & & & 7 \\
\hline En az 10 yıl tecrübesi olan öğretim görevlileri & \multirow[t]{2}{*}{ Tecrübeye göre } & & 1 \\
\hline $\begin{array}{l}\text { Akademik Türkçe öğretiminde uzmanlaşmış } \\
\text { öğreticiler }\end{array}$ & & & 1 \\
\hline Akademik yayın yapan öğreticiler & $\begin{array}{l}\text { Yayın yapma becerisine } \\
\text { göre }\end{array}$ & & 3 \\
\hline $\begin{array}{l}\text { Öğretici eğitimi için kurs programının } \\
\text { düzenlenmesi }\end{array}$ & Hizmet içi eğitim & \multirow[t]{3}{*}{$\begin{array}{l}\text { Öğreticilerin mesleki } \\
\text { gelişimi }\end{array}$} & 7 \\
\hline Öğreticilere lisansüstü eğitim imkânı sunulması & Lisansüstü Eğitim & & 1 \\
\hline $\begin{array}{l}\text { Fakültedeki öğretim üyeleriyle koordineli } \\
\text { olunması }\end{array}$ & Uzman desteği & & 6 \\
\hline
\end{tabular}

Yukarıdaki tabloda akademik Türkçe dersini yürütecek öğreticilerin özellikleri ve mesleki gelişimleri için kodlara yer verilmiştir. Katılımcılar, akademik Türkçe dersini kimlerin vermesi gerektiğini belirtirken öğrenim durumu, tecrübe ve yayın yapma becerisine göre hareket etmiştir: TÖMER'lerde görevli öğretim görevlileri ( $\mathrm{f}=7$ ), içerik odaklı Akademik Türkçe eğitimi verilmesi gerektiğinden fakültelerdeki öğretim üyeleri ( $f=7)$, doktora mezunu öğreticiler $(f=4)$, akademik yayın yapan öğreticiler $(f=3)$, en az yüksek lisans mezunu olanlar ( $f=2)$, TÖMER'lerde en az 10 ylllık öğreticilik yapanlar $(f=1)$ ve akademik Türkçe öğretiminde uzmanlaşmış öğreticiler $(\mathrm{f}=1)$ katılımcıların ifade ettiği görüşlerdir. Öğreticilerin mesleki gelişimi için hizmet içi eğitim verilmesi $(\mathrm{f}=7)$, fakültelerdeki öğretim üyeleriyle koordineli olunması ( $f=6)$ ve lisansüstü eğitim imkânı sunulması $(f=1)$ gerektiği belirtilmiştir. Aşağıda katılımcı görüşlerine örnekler verilmiştir:

Akademik Türkçe dersini yüksek lisans yapma asgari şartını sağlayan Türkçe öğreticileri vermelidir. Bununla birlikte ileri düzey akademik Türkçe kurslarl için çeşitli fakültelerde görev yapan öğretim üyelerinden de istifade edilmelidir. (1K)

Doktorasım bitirmiş hocalar verebilir. (3K)

İcerik odakh akademik Türkçe eğitim planlanacaksa sosyal, fen ve sağhk olmak üzere her fakülteye ait birimde alan uzmanları tarafindan verilebilir. $(5 \mathrm{~K})$

Akademik Türkçe dersinin farkh hocalar tarafindan verilmesi öğrencinin lisans eğitimi sirasında yaşayabileceği sıkıntıları ortadan kaldırabilir. Türkçe hazırlık eğitimi sırasındaki hocalar devam ederse, öğrenciler bunun farkh bir eğitim olduğunu kavrayamayacaklardır. (1oK)

Akademik Türkçe öğretimi üzerine uzmanlaşmış öğreticilere ihtiyaç söz konusudur. Bunu başarabilmek için de YÖK koordinasyonunda özel bir birim oluşturulmahdır. (18K)

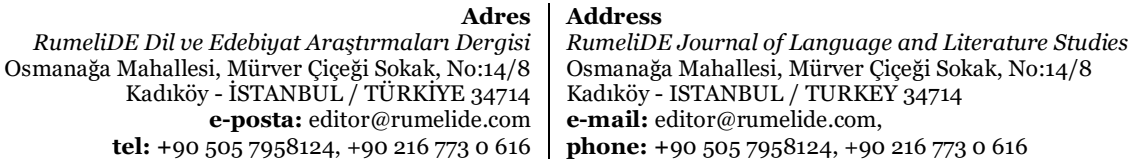


TÖMER çalş̧anları vermeli. Bu çahşanlara gerekçelendirmeli metinlerin üretimi ve çözümlendirilmesi, akademik ve teknik söz varh̆̆ı konusunda bilgilendirme yapılmah. Bu nedenle akademik Türkçe dersinde kullanılacak dil bilgisi yapıları ve söz varhı̆ı unsurları belirlenmeli ve öğretim görevlileri bu konuda bilgilendirilmelidir. (20K)

Akademik Türkçe dersini TÖMER Hocalar ile fakültelerdeki uzman akademisyenler vermelidir. TÖMER Hocalarn için bu aym bir uğraştır çünkü öğrettikleri alandaki terminolojiye hakimiyet gerektirir. Fakültelerdeki uzman akademisyenlerin ise akademik Türkçe dersini verirken, yabancı öğrencilere onlarn seviyesinde anlatması gerekir. Bu da yine özel bir çaba gerektirir. Meslek gelişimi için, fakültelerdeki uzman akademisyenlere, yabanclara Türkçe öğretimi için seminerler ve sertifikalar verilmesi en kısa süreçte yol alınmasını sağlayacaktır. (21K)

\section{Araştırmanın beşinci alt problemine ilişkin bulgular}

Tablo 6. "Akademik Türkçe dersi için sözlük özellikleri” teması

\begin{tabular}{ll}
\hline Kodlar & $\mathrm{f}$ \\
\hline Alan bazlı terim sözlüklerinin hazırlanması & 12 \\
\hline Türk Dil Kurumu Genel Ă̆ adresindeki sözlüklerden yararlanılması & 10 \\
\hline Derlem çalışmalarından yararlanılması & 5 \\
\hline Akademik Türkçe dersine yönelik müstakil bir sözlüğün mümkün olmaması & 2 \\
\hline Genel akademik kavramlar sözlüğünün hazırlanması & 2 \\
\hline
\end{tabular}

Akademik Türkçe dersi için sözlük özellikleri temasına yönelik kodlar Tablo 6'da gösterilmiştir. En çok alan bazlı terim sözlüklerinin hazırlanması $(\mathrm{f}=12)$ önerilmiştir. Bazı katılımcılar Türk Dil Kurumu'nun genel ağ adresinde bulunan sözlüklerin yeterli olacağını belirtmiştir $(\mathrm{f}=10)$. Derlem çalışmalarından yararlanılması $(f=5)$, genel akademik kavramlar sözlüğünün hazırlanması $(f=2)$ ve bu derse ilişkin müstakil bir sözlüğün olamayacağı $(f=2)$ belirtilen diğer görüşlerdir. Aşağıda katılımcı görüşlerine örnekler verilmiştir:

Bu derse yönelik müstakil bir sözlüğün yazılabileceğini düşünmüyorum. Ancak farkl farkh branşlarm kavram sözlükleri yapılırsa bu olabilir. Örneğin ekonomi terimleri sözlüğü, eğitim terimleri sözlüğü, top terimleri sözlüğü vb. Ancak bu tarz sözcükler ilgili bölümlerde öğrenim gören öğrencilere fayda sağlayabilir. Genel bir sözlüğün üretilemeyeni, üretilirse de yararh olmayacağını düşünüyorum. (1K)

Her disipline özgü temel terminolojiler sözlüğü hazırlanabilir. Bu sözlükte kelimelerin geçtiği bağlamlar da sunulmalıdır. Ayrıca kaynak önerisi niteliğinde linkler bulunabilir. (6K)

Akademik Türkçe dersinin amacı öğrencinin artık bir Türk gibi okuması, yazması, dinlemesi ve okumasıdır. Bu sebeple TDK’nin Türkçe Sözlüğünü anlaması gerekmektedir. Bunun haricinde bir sözlüğü gerek olduğunu düşünmüyorum. (10K)

Alanyazındaki sözlükler hakkında çok bir bilgim yok. Ancak böyle bir sözlüğün madde başı sözcüklerinin seçiminde titiz davranmak gereklidir. A1-A2'ye sözlük hazırlarmış gibi olmamahdır. Ağırlıkl olarak terimlere bağlaçlara ve öğrenicilere akademik bir yazı yazarken yol gösterici, işlerini kolaylaştırıc nitelikte bolca örnek cümlelere yer veren bir sözlük olmalıdır. (14K)

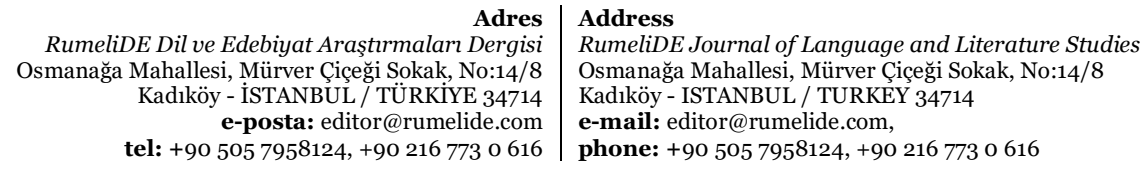


Akademik Türkçenin söz varlı̆̆na yönelik yapılan araştırmalar sonucu elde edilen kelime listeleri (Tüfekçioğlu vb.) tercih edilebilir. Akademik Türkçe ile ilgili bir sözlükte terimler ve örnek cümleleri yer alabilir. (19K)

\section{Araştırmanın altıncı alt problemine ilişkin bulgular}

Tablo 7. "Akademik Türkçe dersi için öğretim materyalleri” teması

\begin{tabular}{|c|c|c|}
\hline Kodlar & Kategoriler & $\mathrm{f}$ \\
\hline Ders kitabı & \multirow{6}{*}{ Materyal türleri } & 11 \\
\hline Bilimsel dergiler & & 1 \\
\hline Akademik metin türleri & & 4 \\
\hline Araştırma teknikleri kitapları & & 1 \\
\hline Alandaki ders kitapları & & 1 \\
\hline Ses/video kayıtları & & 7 \\
\hline Alanlara göre metinlerin olması & \multirow{9}{*}{ Materyallerin özellikleri } & 5 \\
\hline Akademik dil becerilerini geliştirebilmesi & & 4 \\
\hline Akademik dil bilgisinin öğretilmesi & & 3 \\
\hline Öğrenme çıktılarının belirlenmesi & & 1 \\
\hline Akademik konuşma ve yazma odaklı olması & & 2 \\
\hline Öğretmen kılavuz kitabının olması & & 1 \\
\hline Sıklığa dayalı söz varlığı öğretimi & & 2 \\
\hline Ders kitapları mantığından farklı materyaller olması & & 1 \\
\hline İhtiyaç analizine göre materyallerin hazırlanması & & 1 \\
\hline
\end{tabular}

Tablo 7, akademik Türkçe dersi için öğretim materyalleri temasına yönelik on beş kod ve iki kategoriyi içermektedir. Ders kitabı ( $\mathrm{f}=11$ ) ve ses/video kayıtları $(\mathrm{f}=7)$ en çok ulaşılan kodlardır. Akademik metin türlerine yönelik örnekler $(\mathrm{f}=4)$, bilimsel dergiler $(\mathrm{f}=1)$, araştırma teknikleri kitapları $(\mathrm{f}=1)$ ve alana yönelik ders kitapları $(\mathrm{f}=1)$ diğer verilerdir. Materyallerin özellikleri olarak katılımcılar en çok alanlara göre metinlerin kullanılmasını ( $\mathrm{f}=5$ ) önermiştir. Bunu sırasıyla materyallerin akademik dil becerilerini geliştirebilecek özellikte olması ( $\mathrm{f}=4$ ), akademik dil bilgisini öğretebilmesi $(\mathrm{f}=3$ ), akademik konuşma ve yazma odaklı olması ( $f=2)$, sıklı̆̆a dayalı söz varlığı öğretimi yapması (f=2), öğrenme çıtılarının belli olması (f=1), öğretmen kılavuz kitabının olması $(\mathrm{f}=1)$, ders kitabı mantığından farklı materyallerin hazırlanması $(\mathrm{f}=1)$ ve ihtiyaç analizine göre hareket edilmesi $(\mathrm{f}=1)$ kodları izlemiştir. Aşağıda katılımcı görüşlerine örnekler verilmiştir:

Öncelikle kitaplar diyebilirim. Kitapların dışında çeşitli konferans, sempozyum, tartışma vb. türlerin ses/video kayntlarn olabilir. (1K)

Üniversitelerin hazırladiğı Akademik Türkçe kitapları sadece temel bir eğitim sağlamaktadır. Vize, final sinavları, ödevler, sunumlar, makaleler, tezler gibi materyaller üzerinde çalışılmahdır. (6K)

Fen, sosyal ve sağlık bilimleri olmak üzere 3 farkh alana özel hazırlanmış ve içeriği bu 3 alanın metin ve kelimelerinden oluşan sesli, görüntülü ve matbu materyaller. Bunlar içerisinde olmazsa olmazlardan birisi şudur: Her 3 bölümdeki (hem lisans hem de lisansüstü) değişik derslerin ses

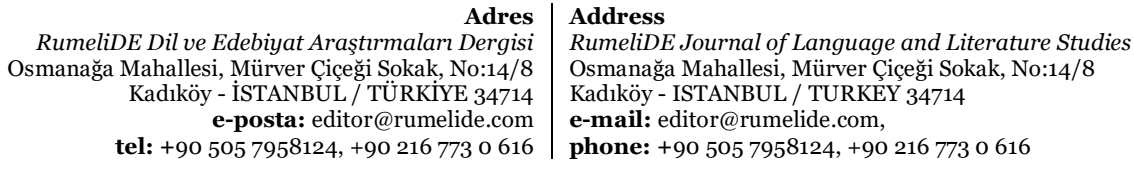


kayıtları tutulmah ve gerekli teknik düzenlemelerden sonra bu ses kayıtları ders materyali olarak kullanılmahdir. (8K)

Bu konuda özel olarak yazılmış yöntem kitaplarından yararlanılabilir. Bununla birlikte bilimsel metinler, röportajlar, demeçler, paneller, bildiriler, bir konu hakkında bilgi veren metinlerden sinıf içerisinde yararlamlabilir. Bu materyaller, akademik söylem ve dilin özelliklerini, akademik metin üretim aşamalarmı doğru yansıtan, etik ihlaller ya da intihal barındırmayan özellikte olmahdır. APA 6 ölçütlerine göre yazılmış olmahdır. Öğretmen tarafindan geliştirilen ders malzemelerinde ise atı yapma, kaynak gösterme, özetleme, intihal yapmama, çerçeve belirleyicileri kullanma, ilgili dil bilgisel yapıları işletme yani sılklkla kullanılan eylem, bağlayıcı, kip/kiplikler vb.ne yer verilmesi gerekir. Öğrenci akademik metnine yönelik taslak oluşturmah, araştırma yapmalı ayn zamanda süreci öğretmen ve akranlarnndan dönütler alarak da planlayıp yönetebilmelidir. Öz değerlendirme yapmasına da olanak sağlanmahdır. (15K)

Akademik Türkçe derslerinde öğrencilerin ihtiyaçlar belirlenmeden bunu söylemek doğru olmayacaktır. Akademik Türkçe sinıfları oluşturulurken öğrencilerin alanları göz önünde bulundurulmalıdır. Burada bu alanlarda ders veren öğretim üyeleri ile de görüşülerek onlarn gözlemlerinden yararlamılmahdır. (18K)

Bu materyallerin belirlenmesinde kesinlikle alaninda uzman kişilerin rol alması gerekmektedir. Örneğin Makine Mühendisliğinde okuyacak bir yabancı öğrenci ile Çevre Mühendisliğinde okuyacak bir öğrencinin ders materyalleri farkh olacaktır. Her ne kadar bu konuda yazılmış Akademik Türkçe kitapları olsa da bölümler farklı olduğundan eksiklikler bulunmaktadır. (21K)

\section{Araştırmanın yedinci alt problemine ilişkin bulgular}

Tablo 8. "Akademik Türkçe dersi için disiplin ayrımı" teması

\begin{tabular}{lll}
\hline Kodlar & Kategoriler & $\mathrm{f}$ \\
\hline Disiplin ayrımının yapılması & & 14 \\
\hline Disiplinlere göre ayrıldıktan sonra bölüm tasnifinin de yapılması & $\begin{array}{c}\text { Disiplin ayrımının } \\
\text { olması }\end{array}$ & 4 \\
\hline Öğrenci sayısına göre hareket edilmesi & & 2 \\
\hline Disiplin ayrımının yapılmaması & $\begin{array}{l}\text { Disiplin ayrımının } \\
\text { olmaması }\end{array}$ & 4 \\
\hline
\end{tabular}

Akademik Türkçe dersi için disiplin ayrımı temasına yönelik ulaşılan dört kod ve iki kategori Tablo 8'de yer almaktadır. Akademik Türkçe öğretiminin disiplinlere göre tasnif edilmiş sınıflarda yapılması en çok ifade edilen görüştür ( $\mathrm{f}=14$ ). Dört katılımıı bu ayrımın yapılmamasını savunmuştur. Disiplinlere göre ayrıldıktan sonra bölüm tasnifinin yapılması görüşünü belirten katılımcıların olması da dikkat çekmektedir $(\mathrm{f}=4)$. İki katılımcı öğrenci sayısına göre hareket edilmesini önermiştir. Aşağıda katılımcı görüşlerine örnekler verilmiştir:

Eğitim programın amactna yönelik ister ortak olarak genel akademik Türkçe olarak bölümleri ayırmaksızın program yapılabilir ister bölümlere yönelik özel akademik Türkçe için program yapulabilir. (5K)

Ayrım yapılması gerekir. Öğrencilerin ilgi duymadıkları alanlara özgü çalışmalar motivasyonlarmı düşürmektedir. (6K)

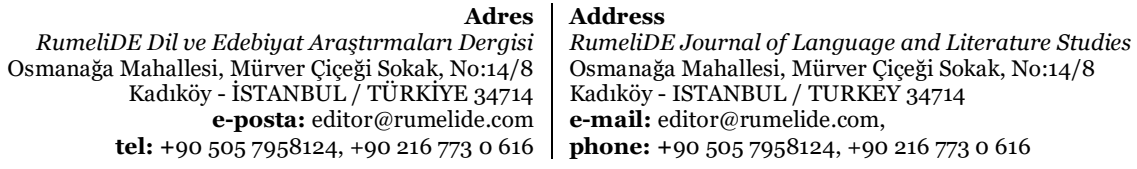


Yapılmamalı diye düşünüyorum. Yapılacak bir ayrtmda ilk olarak öğreticinin yeterliğini sorgulamak gerekir. Eğer bölüm ve dil öğreticisi ortak çahşır ise mümkün olabilir. İki alandan da genel kültür çerçevesinde, öğrenciye öğrenmenin mantıkh geleceği konular seçilmeli ve farkh arka plandan öğrencilerin bulunduğu ortamda öğretim yapılmahdır. (11K)

Kesinlikle ayrlmalıdır. Sosyal, fen, sağlık gibi alt birimlere ayrlldıktan sonra kendi içerisinde de bir tasnife gidilmelidir. Örneğ in iktisat okuyacak bir öğrenci ile Elektronik Müh. okuyacak bir öğrencinin akademik Türkçe ihtiyaçları farkh olacaktır. Bunun için her fakülte biriminde bu ihtiyacı karşılayacak uzman elemanlarm yetiştirilmesi uygun olacaktır. (21K)

\section{Araştırmanın sekizinci alt problemine ilişkin bulgular}

Tablo 9. “Akademik Türkçe dersinin zorunluluğu” teması

\begin{tabular}{lcc}
\hline Kodlar & Kategoriler & $\mathrm{f}$ \\
\hline Bütün uluslararası öğrencilere zorunlu olması & Zorunlu olması & 13 \\
\hline Ana dili Türkçe olan öğrenciler için de zorunlu olması & & 1 \\
\hline Akademik Türkçe dersinin yanı sıra bilimsel hazırlık eğitimi verilmesi & 1 & 1 \\
\hline Sadece lisansüstü eğitim alan uluslararası öğrencilere verilmesi & İsteğe bağlı olması & 5 \\
\hline İsteğe bağlı olarak yapılması & & 1 \\
\hline
\end{tabular}

Tablo 9'da akademik Türkçe dersinin uluslararası öğrencilere zorunlu olup olmamasına yönelik veriler yer almaktadır. En çok bütün uluslararası öğrencilere zorunlu olması $(\mathrm{f}=13)$ görüşü ifade edilmiştir. Beş katılımcı bu dersin isteğe bağlı olmasını belirtmiştir. Birer katılımcı; bu dersin ana dili Türkçe olan öğrenciler için de zorunlu olması, sadece lisansüstü eğitim gören uluslararası öğrencilere verilmesi ve akademik Türkçenin yanı sıra bilimsel hazırlık eğitiminin de verilmesi gerektiğini ileri sürmüştür. Aşağıda katılımcı görüşlerine örnekler verilmiştir:

Türkiye koşullarmda lisans okuyan her uluslararası öğrenci için zorunlu olmalıdır. Bu konuda sadece YTB Burslularının yükümlü bırakılması doğru değil. Diğer öğrencilerin dil yeterlikleri açısından genellikle YTB Burslularmdan daha çok sorunlar yaşadiğı da göz önüne alınırsa, üniversite okuyan tüm öğrencilerin akademik Türkçe dersi görmesi gerektiğini düşünüyorum. (1K)

Bence sadece tüm yabancı öğrenciler için değil aksine Türk öğrencilere de böyle bir eğitim olması zorunlu hale gelmesi gerekmektedir veya en azından en az 1-2 sene boyunca bilimsel araşttrma yöntemleri dersi konulmahdir. (5K)

Zorunlu olmahdır. Biz aksini iddia etsek de bir gün gelecek zorunlu olacakttr zaten. (8K)

Bütün öğrenciler için akademik Türkçe dersinin zorunlu olması gerekiyor. Çünkü öğrenci bölümüne gittiğinde adaptasyon sorunu yaşıyor. Akademik Türkçe dersi verilmeden önce öğrencilerle görüştüğümde büyük çoğunluğunun özellikle ilk dönem pek çok dersten kaldığını öğrendim. Akademik Türkçe eğitimi alan öğrenciler ise alttan dersinin olmadığım ya da 1-2 desten kaldığımı ifade etmişlerdir. (10K)

Akademik Türkçenin lisans düzeyinde gereksiz olduğunu düşünüyorum. Lisansüstü eğitimine devam edecek öğrenciler akademik Türkçeye daha fazla ihtiyaç duymaktadır. Dolayısıyla lisansüstü eğitimle

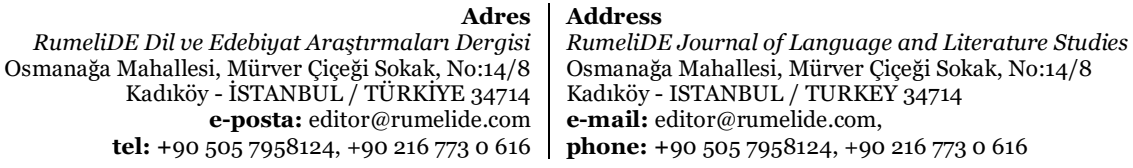


birlikte verilmelidir. Lisansta zaten pek çok ders bulunmaktadır. Öğrenciler bunlarla boğuşurken akademik Türkçeye ne kadar zaman ayıracaklardır muamma. (14K)

Öncesinde yabancllara Türkçe öğretme deneyimim olduğu için şimdi de lisans düzeyinde eğitim verdiğim için akademik Türkçe dersi almayan çoğu öğrencimin gerçekten en basit yönergeleri bile anlamakta güçlük çektiğini görüyorum. Özellikle akademik dili, alanda yazılmış yayınların dilini anlamakta zorlanıyorlar. Kimi öğreniciler bu konuda daha az sıkıntı yaşasalar da kesin olarak neredeyse tümünün akademik metin oluşturmada ciddi slkntıları var. O nedenle böyle bir ayrmın olması büyük bir ikilik yaratacaktır. Dolayısıyla üniversiteden önce öğrenicilerin tamamı akademik Türkçe dersleri almahdır. (15K)

\section{Tartışma, sonuç ve öneriler}

Akademik Türkçe öğretimine ilişkin ders kitabı ve bilimsel metin yazarlarının görüşlerini incelemeyi amaçlayan bu araştırmanın birinci alt bulgusunda öne çlkan veriler şunlardır: Akademik Türkçe dersinin öğrencilerin akademik yazma ve konuşma başta olmak üzere bütün akademik dil becerilerini geliştirmesi ile bu derste akademik söz varlı̆̆ı öğretimi yapılması gibi temel hedefleri olmalıdır. Akademik Türkçe öğretim programının özelliklerine ilişkin araştırmanın ikinci alt bulgusunda ulaşılan veriler şöyle özetlenebilir: akademik anlatma becerileri başta olmak üzere bütün dil becerilerine yönelik kazanımların olması, söz varlığı, yöntem-teknikler, ölçme ve değerlendirme bilgilerine yer verilmesi, programın CEFR temelli ve öğretim elemanı görüşleri dikkate alınarak hazırlanması, ders kitabı yazarlarına, TÖMER’lere ve öğreticilere rehberlik yapabilmesi.

Birinci ve ikinci alt bulgularda katılımclların birbirini destekler nitelikte hem temel hedefler hem de öğretim programı noktasında akademik dil becerileri ve söz varlığı vurgusu yapması dikkat çekmektedir. Araştırmanın ilk iki alt bulgusundaki verilerle ilgili bazı araştırmalar literatürde mevcuttur. Ekmekçi (2017: 283), öğrencilerin alana özgü kavramları bilmedikleri için dinleme ve yazma becerilerinde başarısız olduklarını belirlemiştir. Ayrıca aynı araştırmada akademik Türkçe becerilerini öğrenen uluslararası öğrencilerin yaşadığı problemler arasında akademik konuşamama olduğu (s. 283), tez savunması, hazırlıksız konuşma ve danışmanla iletişim kurma konularında öğrencilerin yetersizlik yaşadığı (s. 285) belirlenmiştir. Ekmekçi’nin (2017) bulguları, bu araştırmada yazarların ifade ettiği temel hedeflerde yazma ve konuşma becerilerine önem verilmesi, söz varlı̆̆ı öğretimi yapılması; öğretim programında akademik anlatma becerileri başta olmak üzere bütün dil becerilerine yönelik kazanımların olması bilgileriyle örtüşmektedir. Demir (2017: 209), uluslararası öğrencilerin akademik Türkçe ihtiyaçlarını ortaya koyduğu araştırmasında öğrencilerin bölüm derslerinde önemli gördükleri hususlardan birinin sinifta dersle ilgili sorular sormak olduğunu (s. 207) ve akademik ortamlarda konuşma becerilerini kullanırken en çok telaffuz hatası yapmadan konuşabilmekte zorlandıklarını (s. 209) belirlemiştir. Demir'in (2017) tespiti, bu araştırmada temel hedeflerde konuşma becerisine ağırlık vermesi ve öğretim programında akademik anlatma becerileri başta olmak üzere bütün dil becerilerine yönelik kazanımların olması bulgusuyla paraleldir. Konyar (2019), uluslararası öğrencilerin öğretim üyelerinin konuşma hızlarından olumsuz etkilendiklerini, en çok derse katkı sağlama hususunda sorun yaşadıklarını (s. 92), dersle ilgili konuşma, belgesel veya video izlerken içeriği anlama ve anladığını ifade etme becerilerinde güçlük yaşadıklarını saptamıştır (s. 87). Konyar'ın (2019) tespitleri, bu araştırmada yazarların belirttiği akademik yazma ve konuşma başta olmak üzere bütün akademik dil becerilerinin geliştirmesi ve öğretim programında akademik anlatma becerileri başta olmak üzere bütün dil becerilerine yönelik kazanımların olması görüşlerini desteklemektedir. Christison ve Krahnke (1986: 70), İngilizcenin en zor akademik kullanımının sınıfta konuşmak ve dersleri dinlemek olduğunu

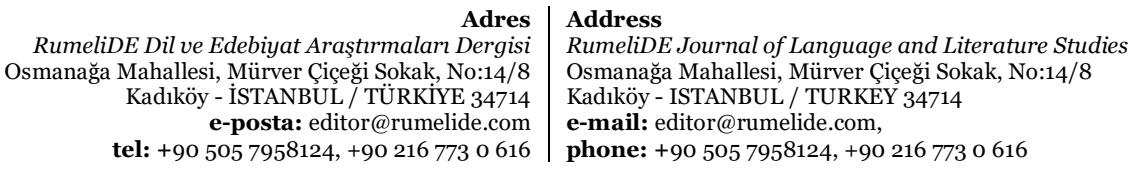


uluslararası öğrenci görüşlerinden hareketle tespit etmiştir. Christison ve Krahnke'nin (1986) bulguları bu araştırmanın bütün akademik dil becerilerinin geliştirmesi bulgusuyla örtüşmektedir. Demir (2017, s. 208), Ekmekçi (2017: 283) ve Seyedi (2019), uluslararası öğrencilerin akademik yazma becerisinde sorun yaşadıklarını belirlemiştir. Araştırmacıların tespiti, mevcut araştırmada yazma becerisine ilişkin ulaşılan temel hedefler ve öğretim programı bulgularını desteklemektedir. Literatürdeki tespitler ile bu araştırmanın bulguları birlikte düşünüldüğünde "Akademik Türkçe dersinin temel hedefleri, dört temel dil becerisini akademik düzeyde kazandırmak ve akademik söz varlığı öğretimi yapmaktır.” sonucuna ulaşılmıştır. Ayrıca akademik Türkçe dersi için dinleme/izleme, konuşma, okuma ve yazma becerilerini akademik düzeyde kazandıracak bir öğretim programına ihtiyaç olduğu sonucu ortaya çıkmıştır.

Araştırmanın üçüncü alt bulgusunda akademik Türkçe dersinin verilme zamanı ve süresine yönelik şu bilgilere ulaşılmıştır: Akademik Türkçe dersinin C1 sonrası veya B2 düzeyinden itibaren verilmesi, lisansüstü öğrenciler için özelleştirilmiş akademik Türkçe dersi olarak verilmesi. Ayrıca ders saati olarak haftalık ve dönemlik saat belirtme gibi birbirinden farklı bilgiler verilmiştir. Memiş (2021: 113), B2 düzeyinin sonundan itibaren derslerde akademik metin türlerine yer verilmesinin akademik Türkçe dersi adına bir çözüm olabileceğini ileri sürmüştür. Ayrıca Global Scale of English Learning Objectives for Academic English’te (Akademik İngilizce İçin Küresel İngilizce Öğrenme Hedefleri Ölçeği, 2019) olduğu gibi akademik dil becerileri kazanımlarının A2 düzeyinden itibaren dağıtılması yaklaşımı da hatırlanmalıdır. Yahşi Cevher ve Güngör'ün (2015: 2273) araştırmasına göre uluslararası öğrencilerin çoğu (\%76) akademik Türkçe derslerinin B2-C1 kur düzeylerinde verilmesi gerektiğini ifade etmiştir. Aynı araştırmada katılımcıların \%19'u lisans öncesi bu dersin verilmesini önermiştir. Literatürdeki bilgiler ile bu araştırmanın ilgili bulguları akademik Türkçe derslerinin ne zaman ve kaç saat verilmesi gerektiğine yönelik ortak bir anlayış olmadığını göstermiştir. Bu durumun ana nedeni araştırmanın ikinci alt probleminde ifade edilen öğretim programı eksikliği olarak düşünülebilir.

Araştırmanın dördüncü alt probleminde akademik Türkçe dersine yönelik öğretici temasına ulaşılmıştır: Bu dersin TÖMER'lerdeki öğretim görevlileri tarafından verilmesi, en az yüksek lisans mezunu öğreticilerin veya doktora mezunu öğreticilerin bu dersi yürütmesi, fakültelerdeki öğretim üyelerinin akademik Türkçe öğretimi yapması öğretici özellikleri kategorisinde ulaşlan verilerdir. Öğreticilerin mesleki gelişimi için de kursların düzenlenmesi ve fakültelerdeki öğretim üyeleriyle koordineli olunması bilgilerine ulaşılmıştır. Seyedi (2019: 99), akademik Türkçe derslerinin içerik odaklı olmasından dolayı TÖMER'lerdeki öğreticiler tarafından verilmesinin yeterli olmayacağını ifade etmiştir. Öte yandan alan uzmanlarının dil öğretimi hususunda öğrencilere destek olamayacağı için alan uzmanlarının öğreticilerle birlikte bu eğitimi vermelerini önermiştir. Yahşi Cevher ve Güngör (2015: 2272) ise uluslararası öğrencilerin en çok bu dersin TÖMER'lerdeki öğreticiler tarafından verilmesini, ardından TÖMER'ler bünyesinde ve fakülteler ile iş birliği içerisinde verilmesi gerektiğini ifade ettiklerini belirlemiştir. Literatürdeki bilgiler ile bu araştırmanın verileri, akademik Türkçe derslerinin kim tarafından verileceğine ilişkin farklı görüşler olduğu sonucunu ortaya çıarmaktadır. Öğrencilerin akademik Türkçe derslerinden beklentilerinin alana yönelik anlama ve anlatma etkinliklerinin olması, TÖMER öğreticilerinin alan içeriklerine hâkim olamaması ve alanlara özgü terimlerin farklılaşması bu durumun nedeni olabilir.

Araştırmanın beşinci alt problemi akademik Türkçe dersinde kullanılabilecek sözlük temasıyla ilgilidir.

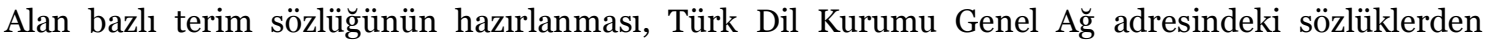
yararlanılması, derlem çalışmalarından yararlanılması öne çıkan bulgulardır. Literatürdeki bazı araştırmalar akademik Türkçe dersi görmeyen uluslararası öğrencilerin alan derslerindeki kavram ve terimleri anlamakta güçlük çektiklerini (Yahşi Cevher ve Güngör, 2015: 2272), uluslararası öğrencilerin

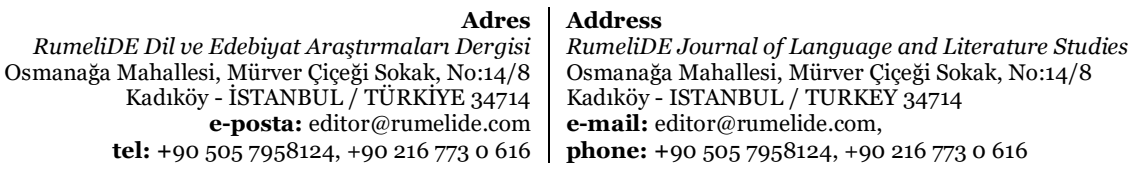


alan terminolojisinden dolayı ders materyallerini okumada zorluk yaşadıklarını (Demir, 2017: 208; Konyar, 2019: 92) saptamıştır. Belirtilen tespitler, akademik Türkçe derslerine ilişkin alan bazlı terim öğretiminin yapılması gerektiğini düşündürmektedir. Ancak Demir'in (2020: 5) "Akademik metinler hiçbir dilde ilgili alanın uzmanı olmayanlarca öylesine anlaşılmaz; akademik metinlerin üretimi gibi anlaşılması da alanla ilgili belli bir bilgi birikimini gerektirir.” görüşü bu hususta dikkate alınmalıdır. Buradan hareketle akademik söz varlığı öğretiminin akademik metin türleri ve özellikleri, metnin bölümleri, akademik dil becerilerinin terimleri, akademik metinlerde karşılaşılan dil bilgisi yapıları temel alınarak yapılabilir. Ayrıca bölümlere özgü teknik söz varlığının öğretilmesi zorunlu olduğunda bu öğretimin basit terimler üzerinden yapılması ve TÖMER’lerdeki öğreticilerin bölümlerdeki uzmanlardan yardım alması önerilebilir. Diğer taraftan "lisans öncesi genel akademik Türkçe", "lisansüstü öğrenim öncesi özel akademik Türkçe" derslerinin zorunlu tutulması, bu derslerin ilkinde lisans düzeyinde gerekli olabilecek genel akademik dil becerileri, ikincisinde ise alana yönelik içerik odaklı akademik dil becerileri öğretimi yapılması düşünülebilir.

Akademik Türkçe dersi için öğretim materyalleri teması araştırmanın altıncı alt bulgusunu oluşturmaktadır. Ders kitabı, ses/video kayıtları ve akademik metin türleri en çok ulaşılan kodlardır. Materyal özellikleri kategorisinde; alanlara göre metinlerin kullanılması, akademik dil becerilerini destekleyecek materyallerin geliştirilmesi, materyallerin akademik dil bilgisi öğretimine imkân vermesi, akademik konuşma ve yazma odaklı olması ve materyallerde sıklığa dayalı söz varlı̆̆ öğretimi yapılması kodları belirlenmiştir. Demir (2020: 111) hem lisans hem de lisansüstü öğrencilerinin en önemli gördüğü akademik okuma etkinliğinin ders kitabı okuma olduğunu saptamıştır. Bunu lisans öğrencileri açısından ders notu okumak, lisansüstü öğrenciler açısından ise bilimsel makale okumanın takip ettiğini belirlemiştir. Aynı araştırmada akademik dinleme açısından ders dinlemek ve derste yapılan tartışmaları takip etmenin önemli kabul edildiği ortaya konulmuştur. Demir’in (2020) bulguları bu araştırmada ulaşılan ders kitabı, ses/video kayıtları ve akademik metin türleri kodlarını desteklemektedir. Akademik Türkçe dersine hitap eden ders materyallerinin daha önceden belirlenmiş temel hedefler ve kazanımlar ışığında hazırlanması ön koşul olarak düşünülmelidir. Aksi takdirde öğrenme girdi ve çıtıları bakımından birbirinden farklı düzeyde uluslararası öğrencilerin olması kaçınılmazdır.

Akademik Türkçe dersi için disiplin ayrımı teması araştırmanın yedinci alt bulgusunu oluşturmaktadır. Disiplin ayrımının yapılması en çok ulaşılan bulgudur. Ayrıca disiplin ayrımının yapılmaması, disiplin ayrımı yapıldıktan sonra bölüm tasnifinin de yapılması ve öğrenci sayısına göre hareket edilmesi kodları tespit edilmiştir. Ekmekçi (2017: 284), araştırmaya katılan öğretim elemanlarının kurs program içeriklerinin alana yönelik düzenlenmesi ve alanla ilgili metinlerin okutulması gerektiğini ifade ettiklerini belirtmiştir. Ayrıca aynı araştırmada öğrencilerin yükseköğrenime başlamadan önce alana özel bir hazırlık sürecinden geçirilmesi gerektiği ifade edilmiştir. Ekmekçi’nin (2017) tespitleri, bu araştırmanın yedinci alt bulgusunda ifade edilen disiplin ayrımı ve bölüm tasnifi görüşlerini desteklemektedir. Bunun yanı sıra Ekmekçi’nin (2017) belirlediği "özel ayrı bir hazırlık sürecinden geçirilmesi” görüşü yukarıda ifade edilen "lisansüstü öğrenim öncesi özel akademik Türkçe dersi” önerisini de desteklemektedir.

Araştırmanın son alt bulgusu akademik Türkçe dersinin zorunlu olup olmamasıyla ilgilidir. Bütün uluslararası öğrencilere zorunlu olması ve isteğe bağlı olarak yapılması öne çıkan bulgulardır. Bir katılımcının ana dili Türkçe olan öğrenciler için de zorunlu olmasını belirtmesi dikkat çekmektedir. Yahşi Cevher ve Güngör (2015: 2272), öğrenci görüşlerine göre fakülte öncesi akademik Türkçe dersi görmenin birtakım yararları olacağını belirlemiştir: Alan derslerini anlamakta kolaylık sağlaması,

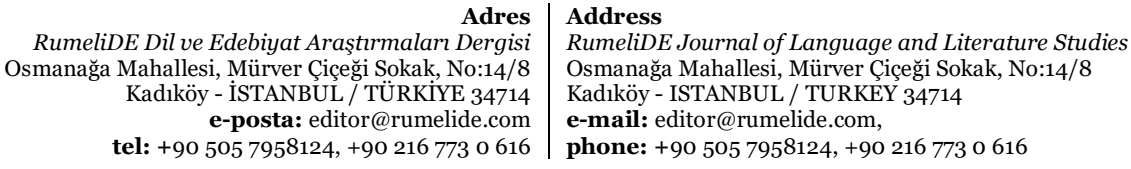


zaman kaybını önlemesi, özgüveni artırması ve alanlara göre farklılaşan terimleri anlamakta yardımcı olması bu yararlardan bazılarıdır. Ekmekçi (2017: 283) de benzer biçimde uluslararası öğrencilerin lisans öğrenimlerinde dil sorunları yaşadığını ve bu sorunların hedef dili öğrenme motivasyonlarına olumsuz etki yaptığını belirlemiştir. Literatürdeki tespitler, bu araştırmada ulaşlan akademik Türkçe dersinin zorunlu olması görüşünü desteklemektedir. Buradan hareketle akademik Türkçe dersinin bütün uluslararası öğrencilere zorunlu olması sonucuna ulaşılmıştır.

Araştırmanın sonuçlarından hareketle aşağıdaki önerilere yer verilmiştir:

- Akademik Türkçe dersi için resmî bir kurum tarafından alan uzmanlarından oluşan bir komisyon oluşturulmalıdır. Bu komisyon "Uluslararası Öğrenciler İçin Akademik Türkçe Dersi Öğretimi Programı”nı hazırlamalıdır.

- “Uluslararası Öğrenciler İçin Akademik Türkçe Dersi Öğretimi Programı”, lisans ve lisansüstü öğrenim düzeyleri dikkate alınarak planlanmalıdır. Birinci düzey, lisans öğrenimi öncesi genel akademik Türkçe becerileri, ikincisi lisansüstü öğrenim öncesi özel akademik Türkçe becerilerini temel almalıdır.

- "Uluslararası Öğrenciler İçin Akademik Türkçe Dersi Öğretimi Programı"nda "Gerekçe, Yaklaşım, Amaçlar, Kazanımlar, Yöntem-Teknik, Ölçme-Değerlendirme, Etkinlik Örnekleri, Akademik Söz Varlığı Listeleri” başlıklarına yer verilmelidir.

- “Uluslararası Öğrenciler İçin Akademik Türkçe Dersi Öğretimi Programı”nda dersin ne zaman verileceği, verilme süresi ve saati bilgileri yer almalıdır.

- Akademik Türkçe dersi nihai olarak öğrencilerin akademik dil becerilerini geliştirmek üzere planlanmalıdır.

- Akademik Türkçe dersini kimin veya kimlerin vereceği ve bu öğreticilerin pedagojik yeterlikleri yasal zeminde belirlenmelidir.

- $\quad$ Akademik Türkçe dersinin materyalleri "Uluslararası Öğrenciler İçin Akademik Türkçe Dersi Öğretimi Programı” doğrultusunda hazırlanmalıdır.

- Genel akademik Türkçe dersi fen, sosyal, eğitim ve sağlık bilimleri ayrımı gözetilerek özel akademik Türkçe dersleri de bölüm tasnifi yapılarak verilmelidir.

- Akademik Türkçe dersi, bütün uluslararası öğrencilere zorunlu olmalıdır.

\section{Kaynakça}

Büyüköztürk, Ş. Kılıç Çakmak, E., Akgün, Ö., E., Karadeniz, Ş. \& Demirel, F. (2008). Bilimsel araştırma yöntemleri. Ankara: Pegem.

Christison, M. A. \& Krahnke, K. J. (1986). Student perceptions of academic language study. TESOL Quarterly, 2O(1), 61-81.

Creswell, J. W. (2013). Nitel araştırma yöntemleri: Beş yaklaşıma göre nitel araştırma ve araştırma deseni. M. Bütün, \& S. B. Demir (Çev. Ed.). Ankara: Siyasal Kitabevi.

Çiftler, F. \& Aytan, T. (2019). Yabancılar için akademik Türkçe kitapları üzerine bir inceleme. IJLET, $7(4), 75^{-91 .}$

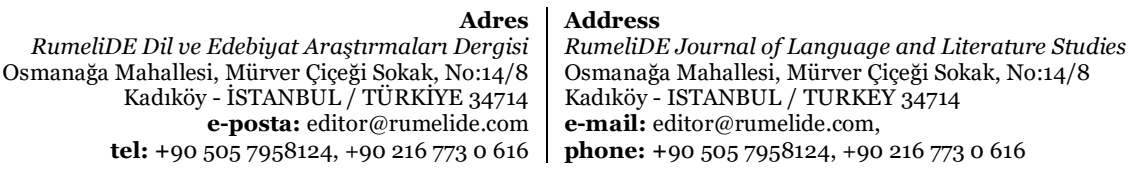


Demir, D. (2017). Uluslararası öğrencilerin akademik Türkçe ihtiyaçları. (Yayınlanmamış doktora tezi). Hacettepe Üniversitesi, Ankara.

Demir, D. (2020, Aralık 4). Uluslararası Öğrenciler için Akademik Türkçe I kitabı üzerine bir değerlendirme (Tam metin bildiri). 2. Uluslararası Eğitim Araştırmaları Kongresi, İzmir, Türkiye. $\quad$ https://akademik.yok.gov.tr/AkademikArama/view/viewAuthorProceeding.jsp adresinden 15.05.2021 tarihinde alınmıştır.

Demir, N. (2020). Akademik Türkçe ve temel sorunları. B. Tüfekçioğlu (Ed.), Akademik amaçlar için Türkçe öğretimi -kuram ve uygulama- içinde, (s. 1-21). Ankara: Pegem.

Demiriz, H. \& Okur, A. (2019). Türkçe öğretiminde yazma öğretimine akademik Türkçe aşamasında yabancı öğrenciler üzerinden bir bakış. Ana Dili Ĕ̆itimi Dergisi, 7(2), 436-449.

Deniz, K. \& Karagöl, E. (2019, Ekim 16-18). Akademik yazma açısından akademik Türkçe ders kitapları. (Tam metin bildiri). XI. Uluslararası Dünya Dili Türkçe Sempozyumu, Samsun, Türkiye. https://drive.google.com/file/d/1H2WOo7ZmKYKLC2vg4_wGzBzUZz8VpK-j/view adresinden 15.05.2021 tarihinde alınmıştır.

Diller İçin Avrupa Ortak Başvuru Çerçevesi. (2020). Common European framework of reference for languages: Learning, teaching, assessment. https://rm.coe.int/common-european-frameworkof-reference-for-languages-learning-teaching/16809eaod4 adresinden 05.02.2021 tarihinde alınmıştır.

Dolmacı, M. (2015). A corpus study of academic Turkish vocabulary: Implications for Teaching Turkish as a foreign language, (Yayımlanmamış doktora tezi). Gazi Üniversitesi, Ankara.

Ekmekçi, V. (2017). Yabancılara Türkçe öğretiminde akademik okuryazarlık öğretimine yönelik bir eylem araştırması, (Yayımlanmamış doktora tezi). Erciyes Üniversitesi, Kayseri.

Er, M. \& Uslu Üstten, A. (2017). Akademik Türkçe öğretiminde yabancı öğrencilerin yazılı anlatım yanlışları üzerine bir değerlendirme (Özet bildiri). Resscongress-Uluslararası Ĕ̆itim Bilimleri ve Sosyal Bilimler Sempozyumu, Balıkesir, Türkiye. https://avesis.gazi.edu.tr/yayin/40a4bfb14294-4193-a090-e1747af86e11/akademik-turkce-ogretiminde-yabanci-ogrencilerin-yazilianlatim-yanlislari-uzerine-bir-degerlendirme adresinden 15.05.2021 tarihinde alınmıştır.

Feller, Rebekah R. (2015). Academic language acquisition. (Master's theses). The College at Brockport: State University of New York.

Global scale of English learning objectives for academic English. (2015). Pearson Education. https://online.flippingbook.com/view/990489/11/ adresinden 09.12.2020 tarihinde alınmıştır.

Göçen, G. (2020). Akademik Türkçe öğretiminde konuşma eğitimi. B. Tüfekçioğlu (Ed.), Akademik amaçlar için Türkçe öğretimi -kuram ve uygulama- içinde, (s. 225-269). Ankara: Pegem.

Göçen, G. (2021). Uluslararası öğrenciler için hazırlanan akademik Türkçe ders kitaplarındaki konuşma görevleri ve yeterlilikleri. Aydın Tömer Dil Dergisi, 6(1), 43-84.

Gürata, E. K. \& Durmuş, M. (2020). Özel amaçlı yabancı/ikinci dil öğretimi kapsamında akademik amaçlı Türkçenin yeri. B. Tüfekçioğlu (Ed.), Akademik amaçlar için Türkçe öğretimi -kuram ve uygulama- içinde, (s. 41-68). Ankara: Pegem.

Hasırcı Aksoy, S. (2021). Lisansüstü öğrenim gören yabancı öğrencilerin akademik Türkçe özyeterliklerine ilişkin görüşleri. OPUS-Uluslararası Toplum Araştırmaları Dergisi, 17(35), $1705-1728$.

İltar, L. (2021). Türkçeyi Yabancı dil olarak öğrenenlerin C1 yazma sınavındaki dil bilgisi hatalarının düzeylere göre dağılımı. Bayburt Eğitim Fakültesi Dergisi, Yabancı Dil Olarak Türkçe Öğretimi Özel Sayısı, 129-147.

Karagöl, E. (2018). Akademik yazma açısından lisansüstü tezler. (Yayımlanmamış doktora tezi). Gazi Üniversitesi, Ankara.

Kızltepe, Z. (2015). İçerik analizi nedir? Nasıl oluşmuştur? F. N. Seggie \& Y. Bayyurt (Ed.), Nitel araştırma yöntem, teknik, analiz ve yaklaşımları (s. 253-266). Ankara: Anı.

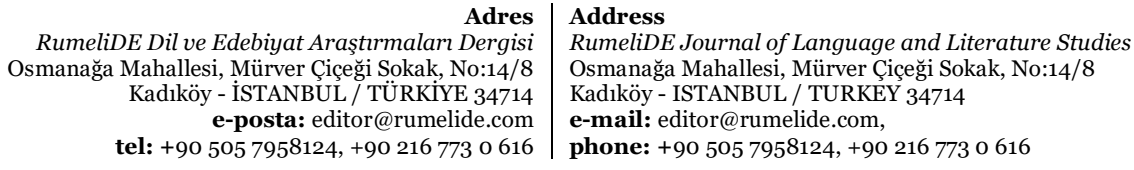


Konyar, M. (2019). Uluslararası öğrencilerin akademik Türkçe ihtiyaç analizi ve örnek ders içeriği. (Yayımlanmamış yüksek lisans tezi). Tokat Gaziosmanpaşa Üniversitesi, Tokat.

Memiş, M. (2021). Yabancılara Türkçe öğretiminin güncel sorunları. Ankara: Pegem.

Miles, M. B. \& Huberman, A. M. (2015). Nitel veri analizi (S. Akbaba Altun, \& A. Ersoy, Çev. Ed.). Ankara: Pegem.

Moralı, G. (2019). Uluslararası öğrencilere yönelik akademik Türkçe okuma metinlerinin ve etkinliklerinin değerlendirilmesi: bir doküman incelemesi. Aydın Tömer Dil Dergisi, 4(2), 57-72.

Özcan, E., Eroğlu, S. \& Demirdöven, G. H. (2018). Akademik Türkçe dersi alan yabancı öğrencilerin okuduğunu özetleme becerilerinin incelenmesi (Özet bildiri). 4th ICPESS, Venedik, İtalya. http://www.registericpess.org/index.php/ICPESS/article/view/1581 adresinden 15.05.2021 tarihinde alınmıştır.

Patton, Q. M. (2014). Nitel araştırma ve değerlendirme yöntemleri. M. Bütün \& S. B. Demir (Çev. Ed.). Ankara. Pegem.

Saban, A. \& Ersoy, A. (2019). Eğitimde nitel araştırma desenleri. Ankara: Anı.

Sallabaş, M. E. \& Korkmaz, C. B. (2019, Ekim 24-26). Uluslararası öğrenciler için akademik Türkçesosyal bilimler ders kitabının tematik yaklaşım bağlamında incelenmesi (Tam metin bildiri). II. Ders Kitapları Uluslararası Sempozyumu, İstanbul, Türkiye. https://avesis.yildiz.edu.tr/yayin/fda3d9c2-4b24-4dfc-8d8c-0137944444ab7/uluslararasiogrenciler-icin-akademik-turkce-sosyal-bilimler-derskitabinin-tematik-yaklasim-baglamindaincelenmesi adresinden 15.05.2021 tarihinde alınmıştır.

Seggie, N. F. \& Bayyurt, Y. (2015). Nitel araştırma yöntemi. F. N. Seggie \& Y. Bayyurt (Ed.), Nitel araştırma yöntem, teknik, analiz ve yaklaşımları içinde (s. 11-22). Ankara: Anı Yayıncılık.

Seyedi, G. (2019). Yabancı dil olarak Türkçe öğretiminde akademik yazma öğretimi. (Yayımlanmamış doktora tezi). Hacettepe Üniversitesi, Ankara.

Seyedi, G. (2020). Akademik dilin yapısı ve genel tanımı. B. Tüfekçioğlu (Ed.), Akademik amaçlar için Türkçe öğretimi -kuram ve uygulama- içinde, (s. 23-39). Ankara: Pegem.

Tavşancıl, E. \& Aslan, A. E. (2001). Sözel, yazılı ve diğer materyaller için içerik analizi ve uygulama örnekleri. İstanbul: Epsilon.

Tüfekçioğlu, B. (2018). Yabancı dil olarak akademik Türkçe: Sosyal bilimlerde akademik ve teknik söz varlıği, (Yayımlanmamış doktora tezi). Hacettepe Üniversitesi, Ankara.

Uslu Üstten, A. \& Yllmaz, H. (2020). An evaluation of the mistakes made by native Arabic speakers in their writing assignments of academic Turkish course. International Journal of Curriculum and Instruction, 12(2), 815-832.

Ülper, H. (2019). Okuma ve anlamlandırma becerilerinin kazandırlması. Ankara: Nobel.

Yahşi Cevher, Ö. \& Güngör, C. (2015). Yabancı dil olarak Türkçe öğretiminde akademik Türkçenin önemine ilişkin uygulamalı bir araştırma: türk dili öğretimi uygulama ve araştırma merkezi örneği. IJLET (UDES 2015), 2267-2274.

Yıldırım, A. ve Şimşek, H. (2008). Sosyal bilimlerde nitel araştırma yöntemleri. Ankara: Seçkin.

Yüksek Öğretim Kurulu. (2019). Seçmeli akademik Türkçe dersi. 22.03.2019 tarihli ve 75850160302.01.02-E.20764 sayll yazl.

\section{Extended abstract}

\section{Introduction}

The ultimate goal of the Academic Turkish course is to improve the academic language skills of its students. It is more of a quality for international students to adapt to higher education and to provide

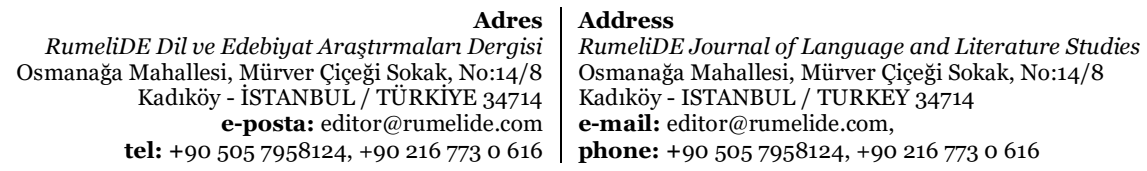


students with the academic language skills required at this level. However, the problems such as the lack of curriculum of the said course, the time and duration of its teaching, its instructional features, materials, the fact that the classes are not formed according to the disciplines (social, science, health sciences) and the course is/is not compulsory have still not been resolved. In order to contribute to the solution of the mentioned problems, the opinions of academic Turkish textbook authors and those who produce scientific texts in this field are important. The aim of the research is to examine the views of textbook and scientific text writers on academic Turkish teaching (basic objectives, curriculum, time and duration of the course, instructive features, dictionary and course book qualifications, disciplinary distinction, and whether the course is compulsory or not).

\section{Methodology}

In the research, which was designed as a qualitative case study, data were collected through semistructured interview form from twenty-one authors who prepared a textbook and scientific text for academic Turkish teaching. The data in the research were collected using a semi-structured interview form. In the first part of the form, which consists of two parts, the educational status of the researchers, their TÖMER experience and their academic Turkish teaching status; In the second part, there are eight questions to collect data on sub-problems. The draft question texts prepared by the researchers were sent to three field experts who have scientific research on teaching Turkish as a foreign language and academic Turkish. After the feedback from the field experts, a preliminary application was made and the questions were finalized. Data were evaluated with inductive content analysis.

\section{Findings and discussion}

"The main objectives of the Academic Turkish course are to acquire four basic language skills at an academic level and to teach academic vocabulary." conclusion has been reached. In addition, it has emerged that there is a need for a curriculum that will provide listening/watching, speaking, reading and writing skills at an academic level for the academic Turkish course. It showed that there is no common understanding about when and how many hours academic Turkish lessons should be given. The main reason for this situation can be considered as the lack of curriculum expressed in the second sub-problem of the research. The result is that there are different opinions about who will teach academic Turkish lessons. The reason for this situation may be that students' expectations from academic Turkish lessons are comprehension and explanation activities related to the field, TÖMER teachers' inability to master the field contents and the differentiation of field-specific terms. It has been concluded that the academic Turkish course is compulsory for all international students.

*Çalışmaya iki yazar da eşit oranda katkıda bulunmuştur.

*Çalışma için Zonguldak Bülent Ecevit Üniversitesi İnsan Araştırmaları Etik Kurulundan 38561 sayılı belge ile gerekli izinler alınmıştır.

\footnotetext{
\begin{tabular}{r|l} 
Adres & Address \\
RumeliDE Dil ve Edebiyat Araştırmaları Dergisi & RumeliDE Journal of Language and Literature Studies
\end{tabular}

Osmanağa Mahallesi, Mürver Çiçeği Sokak, No:14/8 $\quad$ Osmanağa Mahallesi, Mürver Çiçeği Sokak, No:14/8

Kadıköy - ISTANBUL / TÜRKIYE 34714 Kadıköy - ISTANBUL / TURKEY 34714

e-posta: editor@rumelide.com e-mail: editor@rumelide.com,

tel: +90 505 7958124, +90 2167730616 phone: +90 505 7958124, +90 2167730616
} 